San Jose State University

SJSU ScholarWorks

Master's Theses

Master's Theses and Graduate Research

Spring 2020

\title{
Understory Response to Restorative Thinning in Coast Redwood Forests
}

Alyssa Hanover

San Jose State University

Follow this and additional works at: https://scholarworks.sjsu.edu/etd_theses

\section{Recommended Citation}

Hanover, Alyssa, "Understory Response to Restorative Thinning in Coast Redwood Forests" (2020). Master's Theses. 5098.

DOI: https://doi.org/10.31979/etd.uwjr-n68d

https://scholarworks.sjsu.edu/etd_theses/5098

This Thesis is brought to you for free and open access by the Master's Theses and Graduate Research at SJSU ScholarWorks. It has been accepted for inclusion in Master's Theses by an authorized administrator of SJSU ScholarWorks. For more information, please contact scholarworks@sjsu.edu. 


\title{
UNDERSTORY RESPONSE TO RESTORATIVE THINNING IN COAST REDWOOD FORESTS
}

\author{
A Thesis \\ Presented to \\ The Faculty of the Department of Environmental Studies \\ San José State University \\ In Partial Fulfillment \\ of the Requirements for the Degree \\ Master of Science
}

by

Alyssa Hanover

May 2020 
(C) 2020

Alyssa Hanover

ALL RIGHTS RESERVED 
The Designated Thesis Committee Approves the Thesis Titled

\title{
UNDERSTORY RESPONSE TO RESTORATIVE THINNING IN COAST REDWOOD FORESTS
}

\author{
by
}

Alyssa Hanover

APPROVED FOR THE DEPARTMENT OF ENVIRONMENTAL STUDIES

\author{
SAN JOSÉ STATE UNIVERSITY
}

May 2020

William Russell, Ph.D.

Benjamin Carter Ph.D.

Erik Jules Ph.D.
Department of Environmental Studies

Department of Biological Sciences

Department of Biological Sciences, Humboldt State University 



\section{ABSTRACT \\ UNDERSTORY RESPONSE TO RESTORATIVE THINNING IN COAST REDWOOD FORESTS}

by Alyssa Hanover

Restoration of late seral features in second-growth Sequoia sempervirens forests is an important management concern, as so little of the original old-growth remains. The abundance of herbaceous species provides a metric for assessing recovery in these forests where associated understory plants are adapted to closed canopy conditions. Data were collected using a stratified random sampling design across three treatments: mechanically thinned second-growth, un-thinned second-growth, and old-growth reference stands. Pairwise PerMANOVA indicated greater abundance and diversity of native herbs in oldgrowth and un-thinned second-growth compared to thinned stands, as well as higher measures of canopy cover, basal area, and dominance of $S$. sempervirens. Thinned plots exhibited lower stand density than un-thinned stands but also higher abundance of nonnative herbs. Non-metric multidimensional scaling suggested that un-thinned sites were more similar to old-growth than thinned sites in regard to understory composition and abundance, and indicator species analysis returned a suite of indicator species shared between un-thinned plots and old-growth plots while thinned plots shared one indicator with old-growth. In addition, both old-growth and un-thinned second growth sites were dominated by residual species, while thinned plots were dominated by invader species. These results suggest that while mechanical thinning of second-growth $S$. sempervirens stands may provide temporary effects to stand structure and composition, these treatments do not support the recovery of late seral understory species. 


\section{ACKNOWLEDGMENTS}

First and foremost I would like to thank my family for supporting me through this journey full of ups and downs. To my daughter, Kylie, for being my drive and motivation to finish my degree. For sharing my time with my research, even though you did not always want to, and for being the one always there and willing to type the ' $\mathrm{k}$ ' for me. I would also like to thank my thesis chair, mentor, and friend Dr. Will Russell for motivating me to pursue a graduate degree and for being there to support me throughout this journey. Your passion and drive to protect these forests is infectious and I am truly grateful to have had the honor of working with you. To my thesis committee, Dr. Ben Carter and Dr. Erik Jules for providing me with much appreciated help navigating the stats from this project and for all the feedback along the way. I would like to thank the Kiwanis Club of West San Jose and the Native Plant Society for their generous scholarships. As well as the National Park Service and Redwood Nation Park for facilitating access to study sites and providing much need maps and historical data. 


\section{TABLE OF CONTENTS}

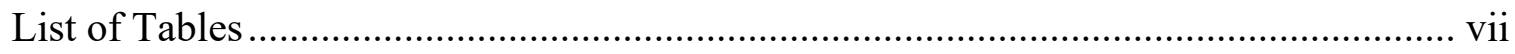

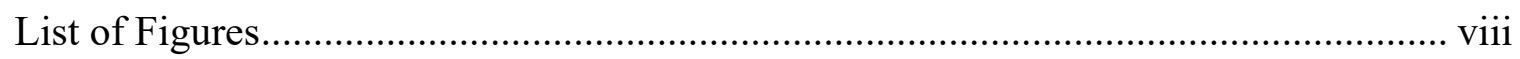

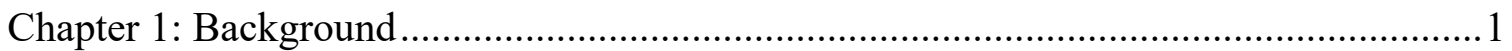

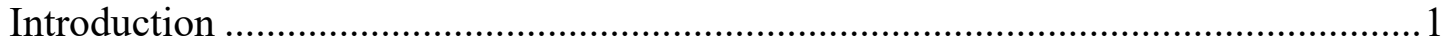

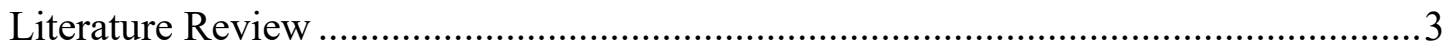

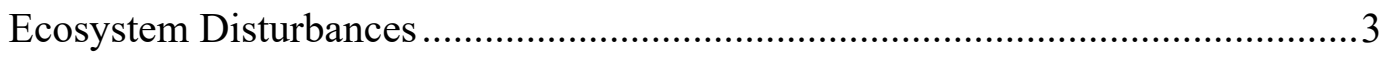

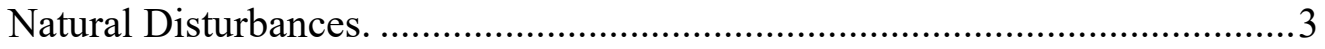

Anthropogenic Disturbances. ..................................................................6

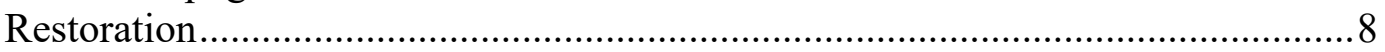

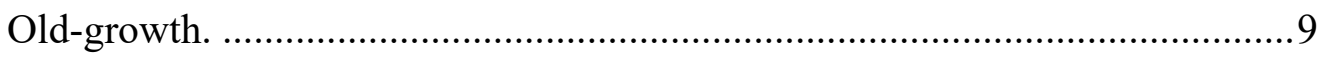

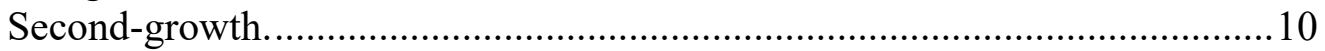

Successional Models. ............................................................................... 11

Succession Within Forest Ecosystems. ...................................................... 12

Active Management..................................................................................... 14

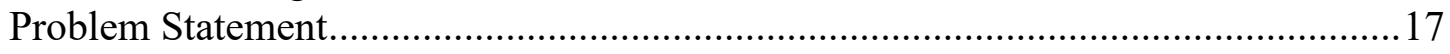

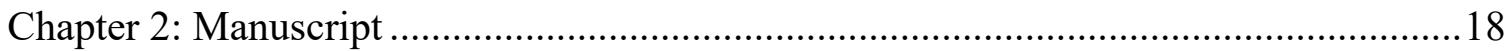

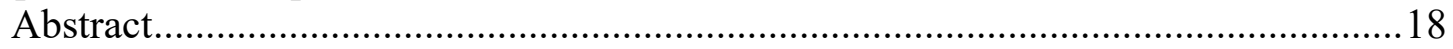

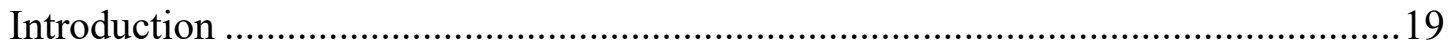

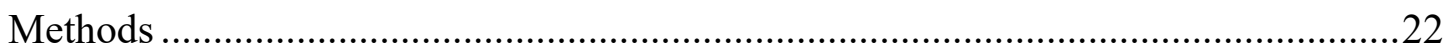

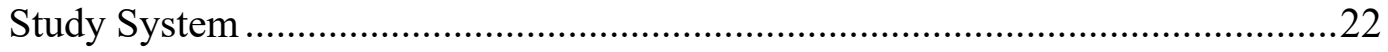

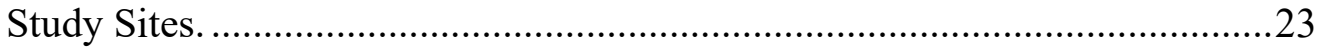

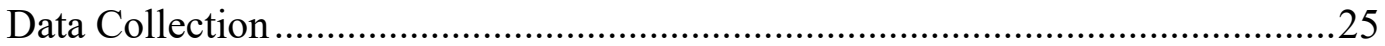

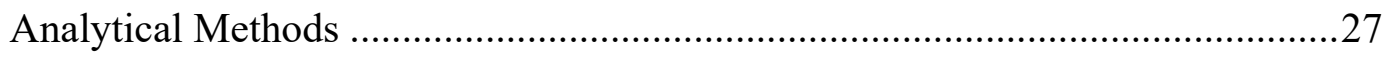

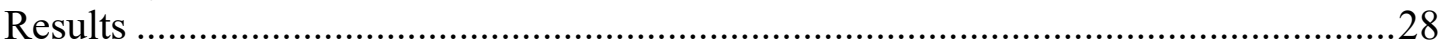

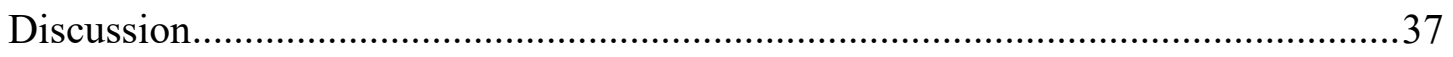

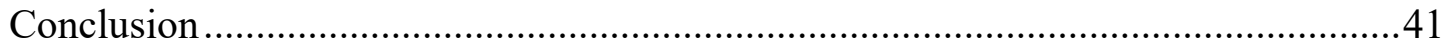

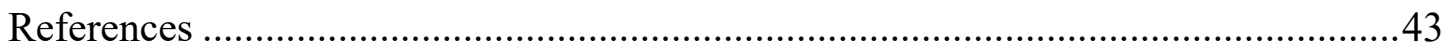

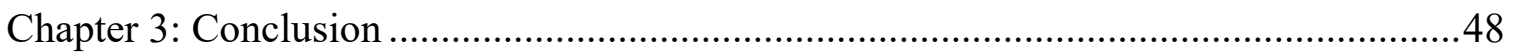

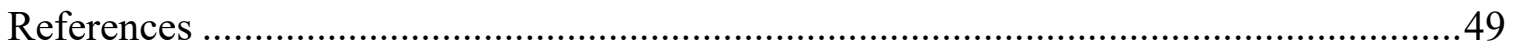

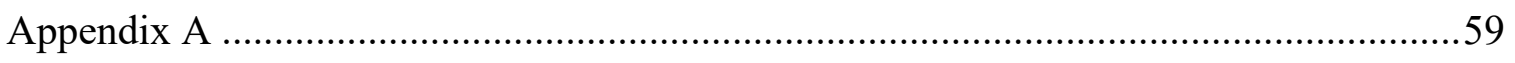




\section{LIST OF TABLES}

Table 1. Site characteristics for nine sites within three treatments at Redwood National Park

Table 2. Mean, standard error (S.E.), and p-value for each physiographic metric, canopy metric, and understory metric measured within each treatment.

Table 3. Significant findings of Kruskal Wallis H Tests comparing percent cover of individual herbaceous species between treatments.

Table 4. Results of indicator species analysis for all understory species data collected within the three treatments at Redwood National Park

Table 5. Mean percent cover for each understory species encounter within the three treatment types at Redwood National Park. 


\section{LIST OF FIGURES}

Figure 1. Average size class tree density per species on old-growth plots (OG), unthinned plots (UT), and thinned plots (T) in Redwood National Park.

Figure 2. Mean percent cover and mean species richness per plot for native herbaceous vascular plant understory, native shrub understory and total native understory within the three treatment types in Redwood National Park.

Figure 3. Nonmetric Multidimensional Scaling ordination of the understory composition in 90 plots across three treatments in Redwood National Park. .32

Figure 4. Mean percent cover per plot for residual and invader herbaceous vascular plant understory within the three treatment types in Redwood National Park.

Figure 5. Diagram showing individual treatment indicator species and indicator species shared between treatments.

Figure 6. Average tree density of the three dominant tree species in the South Fork of Lost Man Creek treatment area.

Figure 7. Examples of slash remaining on thinned sites in Redwood National Park ten years post-thinning.

Figure 8. Examples of slash remaining on thinned sites in Redwood National Park ten years post-thinning. 


\section{Chapter 1: Background}

\section{Introduction}

Anthropogenic disturbance in the form of logging causes major impacts to forests worldwide. Due to human disturbance, the world has lost 1.8 billion hectares of forested land through deforestation and land conversion (Williams 2003). In addition, large amounts of primeval forests have been converted to second-growth stands. Historically, logging has had significant effects on forest communities leading to an increased presence of non-natives, degradation of soil, and long-lasting effects on understory assemblages (Battles et al. 2001; Moola \& Vasseur 2004; Burke et al. 2008; Miesel et al. 2009). Vast areas of forest lands in North America have been harvested since European colonization, with the majority of the primeval coniferous forests of the Pacific Coast falling prey to clear-cuts in the last century and a half (Russell et al. 2014). Though clear-cutting as a timber harvest practice has diminished somewhat in the United States in recent years, silvicultural practices still pose significant threats to forest ecosystems.

Using timber harvest practices to alleviate these threats is counterintuitive, yet active timber management techniques such as stand thinning are currently being promoted as a tool for restoring old-growth characteristics in second-growth stands (O'Hara et al., 2010; Berrill et al. 2013). While these techniques are effective at increasing the growth rate of remaining trees, as they are in traditional timber management (Nyland 2016), their potential impacts on the forest community as a whole are not well understood. For some forest ecosystems, allowing the forest to recover naturally is an effective technique that enables forests to regenerate through inherent processes, without reintroducing the 
impacts associated with logging. Historically, second-growth Sequoia sempervirens (Coast redwood) forest preserves have been managed with minimal effort due to their high resilience and regenerative properties (Fritz 1932).

In the S. sempervirens forest of California, the impacts of timber harvest include the suppression of shade tolerant associated understory species, the introduction of nonnative species, and the interruption of natural successional processes that lead to the production of old-growth structural characteristics. Once covering an estimated 800,000 ha along the west coast of the United States, approximately only $5 \%$ of the original $S$. sempervirens forests remain today (Noss 1999). The remainder is composed of postharvest second-growth forests, including both actively managed stands and preserves where natural processes have traditionally been allowed to reassert themselves. With so little of the original old-growth remaining, there is growing interest in restoring characteristics associated with old-growth to these maturing second-growth stands. The best method of achieving this goal is debated, however, and some preserves are open to logging for the first time under the rubric of increasing "forest health."

Currently, there is no consensus on the metrics that should be used to measure forest health, and managers have defaulted to silviculture measures with little intrinsic ecological value such as tree diameter and stand density. The recovery of herbaceous understory species associated with S. sempervirens forests may provide more effective metrics of forest recovery, as much of the plant diversity in the S. sempervirens forest is found in the understory (Gilliam 2007), and many of these species are sensitive to logging (Loya \& Jules 2008; Russell \& Michels 2011). 


\section{Literature Review}

\section{Ecosystem Disturbances}

An ecosystem disturbance, as defined by White and Pickett (1985), is "any relatively discrete event in time that disrupts ecosystems, community, or population structure and changes resources, substrate availability, or the physical environment." The varying types, intensities, and frequencies of disturbances that a landscape experiences lead to a landscape level ecological mosaic (Forman \& Gordon 1981). Anthropogenic disturbances also affect ecosystem development, and have been introduced at a landscape scale, dramatically altering ecosystems and successional trajectories.

Natural Disturbances. Natural disturbances of varying intervals and intensities provide opportunities for new individuals (of the same or different species) to establish themselves (Sousa 1984). Over time, species evolve different ways of responding to disturbances leading to variations in plant assemblages, niche communities, and increased biodiversity (Hughes 2010). Natural disturbances come in many forms; the most common types are wind, fire, flood, landslides, as well as insect and animal damage.

Wind can be a pervasive disturbance for many ecosystem types. For example, in ecosystems with little vegetative cover or organic material protecting the soil surface, wind can become a major source of erosion (Belnap \& Gillette 1997). Additionally, catastrophic wind damage caused by extreme weather events can drastically affect both terrestrial and aquatic ecosystems. Forest ecosystems can be both directly and indirectly influenced by wind through stem damage, uprooting, and modification of microclimates (Konopka et al. 2016). 
Historically, fire regimes have influenced the composition and structure of many ecosystems. For example, fire is an important factor affecting the maintenance and spread of grasslands (Axelrod 1985). Chaparral communities depend on fire to stimulate seed germination (Keely 1987). In addition, various fire regimes influence structure and composition of forests, often leading to multi-aged stands with complex vertical and horizonal heterogeneity (Baker 1993). Fires can also help reduce stand density while promoting growth of fire-resistant species.

In coast redwood forests, Sequoia sempervirens have evolved to be remarkably resilient to natural disturbances. Sequoia sempervirens forests experience frequent high intensity wind events where gusts over $100 \mathrm{~km} / \mathrm{h}$ can occur between the months of November and April (Lorimer et al. 2009). Windfall is the single most pervasive natural disturbance in this forest type, causing the highest rate of mortality to individual trees. Sequoia sempervirens are most susceptible to wind following long rainy seasons, with older trees falling victim due to their sheer size and shallow root systems. Uprooting was found to be four times more common than snapping for S. sempervirens (Boe 1966). Wind damage can lead to trunk reiterations and course woody debris accumulation in the canopy, which in turn leads to canopy complexity and specialized niche habitats (Sawyer et al. $2000_{a}$ ).

In addition to wind, data have shown that fire has been present in $S$. sempervirens forests throughout history (Jacobs et al. 1985; Brown \& Swetnam 1994; Lorimer 2009). Low to moderate intensity episodic surface fires have played a crucial role in influencing ecosystem patterns in S. sempervirens forests (Fritz 1932; Brown 2007; Lorimer 2009). 
With thick resin-free bark, S. sempervirens are remarkably resistant to fire (Sawyer $2000_{a}$ ). Frequent surface fires often kill sprouts and younger trees before they have a chance to reach the canopy, leading to low-density stand structure and composition that favors S. sempervirens (Brown 2007). In addition, shrub abundance is reduced while herbaceous understory richness and diversity increases as a result of low intensity surface fires (Brown 2007).

Along with wind and fire, floods are routine in the coast redwood region (Sawyer et al. 2000). Through stochastic flooding events, sediment deposits along riverbanks, building up nutrient rich soil and creating alluvial flats (Lorimer et al. 2009). The largest S. sempervirens are found on these alluvial flats. In addition, when faced with increased sediment loads from flooding, S. sempervirens send new advantageous roots up from the main root ball to re-establish in the sediment layer (Stone \& Vasey 1968).

Further adding to their resiliency, S. sempervirens have been shown to be remarkably resistant to animal and insect damage, though one species impacting $S$. sempervirens is Ursus americanus (American black bear). Mortality due to feeding damage tends to affect only pole size trees (Russell et al. 2001; O’Hara et al. 2010; Perry et al. 2016). In addition, feeding damage is most common in second-growth stands and does not appear to be an issue in old-growth (Russell et al. 2001). In a study looking specifically at bear damaged in thinned second-growth stands, bears damaged significantly more trees on thinned plots than control plots (O'Hara et al. 2010; Perry et al. 2016). Damage induced by bears in a natural recovery setting appears to act as a stochastic natural thinning agent, leading to increased heterogeneity in the stand (Russell et al. 2001). 
Anthropogenic Disturbances. Humans have altered disturbance regimes through fire suppression, introduction of non-native species, logging, and urbanization. Fire suppression has altered the structure and composition of many ecosystem types. In forest previously dominated by Quercus (Oaks), the lack of fire has allowed other species such as Pseudotsuga menziesii (Douglas Fir) to penetrate the canopy and shade out previously dominant species (Devine \& Harrington 2006). Similarly, in grasslands without fire in the landscape, shrub species outcompete native grasses and forbs (Uys et al. 2004). In fire dependent chaparral communities, long periods without fire causes an increase in density and a reduction in diversity (Barro \& Conard 1991). Fire suppression in general has led to increased fuel loading and more catastrophic wildfires.

Timber harvest, and the conversion of forest land for agricultural use, has had catastrophic impacts on forests worldwide. By $1850,65 \%$ of European forests had been converted to cropland and pastures (Kaplan et al. 2009). China followed a similar trend loosing 72\% of forested land by 1840 (Fan \& Doug 2001; Liu \& Tian 2010). In the United States, 25\% of forested land has been converted to other uses since 1630 (United States Department of Agriculture 2014). In addition to land type conversion, harvesting of old-growth forests in the United States has resulted in a loss of $93 \%$ of the ancient forests that existed when Europeans first settled in North America.

Though some Native American people utilized S. sempervirens to build canoes and structures, they typically did so with fallen trees found on the forest floor or as drift logs (Barbour et al. 2001). Large scale harvesting of $S$. sempervirens as a timber resource started in the early 1800 s with European settlement (Sawyer et al. 2000b). Initially, 
timber harvesting was a slow painstaking process where only the most accessible trees were extracted with many left standing. As technology improved, and demands increased, the amount of S. sempervirens logged increased dramatically as did the impacts.

The ecological impacts associated with logging have been well documented (Hagen 1986; Sawyer 2000b; Jameson \& Robards 2007; Russell 2009; Petersen \& Russell 2017). Use of heavy equipment leads to soil compaction which in turn results in significant effects on soil pH, nutrients levels, and increased erosion (Jansson \& Johansson 1998; McNabb et al. 2001; Miesel et al. 2009; Cambi et al. 2015). Further erosion is caused by the loss of stabilizing root systems. Impacts to soil, in turn, can impact vascular understory plant assemblages and lead to increased presence of non-native species (Meier et al. 1995; Moola \& Vasseur 2004; Loya \& Jules 2008; Russell et al. 2014).

Timber harvests open large areas in the canopy effecting microclimates, increasing solar radiation, and colonization of non-native species (Chen et al. 1999). Artificial edges created by timber harvest can have impacts on neighboring forest communities as well, including crown dieback, susceptibility to windthrow, and changes to understory assemblages (Russell \& Jones 2009). The impacts of timber harvest are not limited to plant communities, forest fauna are also dramatically impacted. Logging leads to habitat loss and fragmentation, reducing biodiversity. Specialized habitat features such as reiterated trunks, snags, large woody debris and fire hollows, are also lost, and can take hundreds of years to develop. 


\section{Restoration}

Ecological restoration is defined as the process of repairing human caused damage to the diversity and dynamics of natural indigenous ecosystems (Jackson et al. 1995). The objectives of individual restoration projects vary, but typically fall into one of three categories, restoration of an ecosystem to: (1) mimic some known point in time; (2) a healthy functioning ecosystem; (3) a specific species or ecosystem feature. Each objective faces its own challenges. To restore an ecosystem to some known point in time, land managers often reference historical photographs or personal accounts which only provide a small glimpse into the composition and structure of the target ecosystem. The definition of a healthy ecosystem is subjective and open to interpretation, making this goal challenging to implement. Restoring for a specific species or ecosystem feature could potentially cause impacts to species or features that are not targeted in restoration efforts.

There have been effective restoration projects in previously logged forests that focused on road removal, erosion abatement, stream restoration, and the removal of invasive species. The primary goal of these projects was to help restore ecosystem features to benefit spawning anadromous fish populations. More recently, land managers have focused on restoring structural characteristics associated with old-growth. Competition theory is often used as their guiding framework in designing restoration projects that focus on mimicking the density of idealized old-growth stands. However, some argue that forest restorations efforts should focus not only on obtaining structural 
attributes of old-growth, but prioritize the establishment of overstory-understory feedbacks (Burton et al. 2009).

Old-growth. Old-growth forests are both vertically and horizontally complex (Rapp 2002). As a result of this complexity, old-growth forests are the most biologically diverse terrestrial ecosystems on the planet (Betts et al. 2017). Traditionally, old-growth is defined by an absence of a significant logging history (Bolsinger et al. 1993; Frelich \& Reich, 2003; Bauhus et al. 2009). This original definition was derived by foresters in the early logging days, and old-growth was typically characterized by the presence of old large trees (Rapp 2003). Since, ecologist have come to associate the term old-growth with forests of at least 150 years old that have developed complex structural characteristics, distinctive habitat features, and support diverse groups of flora and fauna (Rapp 2003). Despite these findings, the definition of old-growth is still open for interpretation, and some researchers have focused solely on structural features that are commonly found in old-growth forests, such as old large trees (Wirth et al. 2009; Berrill et al. 2013). The loose definition of old-growth presents some challenges for forest inventories and restoration plans, as outcomes are hinged on what definition is being used.

Defining old-growth in S. sempervirens forests has had similar challenges, with most defaulting to defining old-growth as forests with old large trees, and an absences of significant human disturbance (O’Hara et al. 2010). Various stand characteristics are associated with old-growth $S$. sempervirens forests including relatively low density, structural complexity, presence of snags, accumulation of large woody debris, and the 
establishment of shade tolerant understory communities (Van Pelt \& Franklin 2000; Busing \& Fujimori 2009; Spies 2009). Common herbaceous understory species typically associated with old-growth S. sempervirens forests include: Asuram coudatum (Wild ginger), Clintonia andrewsiana (Red clintonia), Lysimachia latifolia (Pacific star flower), Maianthemum racemosum (False Solomon's seal), Oxalis oregana (Redwood sorrel), Polystichum munitum (Pacific sword fern), Prosartes hookeri (Hooker's fairybells), Scoliopus bigelovii (Fetid adder's tongue), Trillium ovatum (Pacific trillium), and Viola sempervirens (Redwood violet) (Lenihan 1990; Mahony \& Stuart 2000; Russell 2009; Russell et al. 2014; Michels \& Russell 2016; Russell 2020).

Second-growth. Forests that were previously harvested are traditionally referred to as second-growth forests. Stands that regenerate after logging tend to be more even-aged and have increased tree density, especially for the first decade following the disturbance (Rapp 2002; O’Hara et al. 2010). In some areas, such as Redwood National Park, clearcuts were reseeded with species such as $P$. menziesii after harvests leading to a shift in species composition away from S. sempervirens dominance (O'Hara et al. 2010; Teraoka 2012; Teraoka et al. 2017). Many of the impacts associated with logging discussed previously are visible in second-growth forests even after decades of growth. Secondgrowth forests are still viable habitat for many species. In the case of S. sempervirens, second-growth forests serve as buffers and habitat links for the remaining old-growth stands. When second-growth forests are left to recover naturally, self-thinning has been shown to be effective at reducing stand density over time (O'Hara et al. 2010; Russell et al. 2014). In the understory, cover of herbaceous and shrub species was found to be 
equivalent to old-growth in naturally recovering mature second-growth S. sempervirens stands (Russell et al. 2014; Russell 2020). Further, Roberts, and Gilliam (1995) predicted that maximum diversity would be achieved through the return of historic natural disturbance regimes. T. ovatum, a long-lived herb commonly found in old-growth $S$. sempervirens forests, has been found to have more complete recovery on previously logged sites where more time has passed since the last logging event (Loya \& Jules 2007; Russell et al. 2014).

Successional Models. The earliest models of succession were described by Frederic Clements. Clements believed that succession was linear and predictable with a beginning and an end with final permanent stage being a climax community (Clements 1916). Climate was the single determining factor in what variety of vegetation could occur, and every region had one type of climax community that it could achieve (Clements 1916). Clements did not view disturbances as successional drivers, rather he viewed them as having a negative effect on community development, thus prolonging the movement towards the climax state (Clements et al. 1929). Arthur Tansley believed that physical environment was as important as climate in determining ecosystem composition. In addition, he argued that different climax community types could occur (Tansley 1935). Frank Egler (1954) proposed two models to succession, the initial floristics model and relay floristics model. In the initial floristics model all species are present in the soil as propagules after a disturbance event, and changes in dominance over time causes some species to fall off while others thrive (Egler 1954). Relay floristics follows a more Clementsian trajectory, with one group of plants replacing another until a climax 
community is achieved (Egler 1954). In both the initial floristic and relay floristic models the end result is a climax community.

More recently, the classical climax theories of succession have been challenged and found to not apply to many community types (Drury \& Nisbet 1973; Urban \& Shugart 1992). Yet, despite overwhelming empirical evidence, the tendency for ecologists and land managers to see plant vegetation change over time leading to stable climax stage persists. Not everyone agreed with the Clementsian climax theory of succession. For example, Henry Gleason proposed in a series of writings that individual plant characteristics were the driving force behind succession (Gleason 1926). Gleason believed succession was "constant and universal," he disagreed that succession ended in a climax state but rather continued on with no end point (Gleason 1926). Gleason's findings were generally ignored, and climax theory persisted until after Clements' death and only more recently has been accepted in the ecological community.

Succession Within Forest Ecosystems. The most widely accepted model in forest succession was proposed by Oliver (1980). Oliver described four phases of stand development following disturbance; initiation, stem exclusion, understory re-initiation, and the complex stage. Stand initiation immediately follows the disturbance event with regeneration of open space occurring from seeds or sprouts. This phase continues until density increases and the canopy begins to close (Oliver 1980). Intense densitydependent competition occurs during the stem exclusion stage. Here self-thinning takes place and species dominance can be attained through inherent faster growth, persistence, and superior crown position (Oliver 1980). The first two stages are marked by a single 
age cohort. During the understory re-initiation stage more than one cohort can become established under the parent stand leading to increased complexity and heterogeneity (Oliver 1980). The final stage occurs when natural mortality leads to canopy gaps which are then filled by younger trees leading to a multi-aged complex forest (Oliver 1980).

The stand development theory that Oliver describes fails to consider the development of biological legacies (Franklin et al. 2007). Biological legacies as described by Franklin et al. (2000) are "the organisms, organic matter (including structures), and biologically created patterns that persist from the pre-disturbance ecosystem and influence recovery processes in the post-disturbance ecosystem.” These biological legacies can influence recovery trajectory and be a driving force behind the rate at which an ecosystem recovers (Franklin et al. 2000). Franklin et al. (2002) argues that current knowledge of structural complexity, developmental processes, duration of development, and existence of complex spatial patterns is lacking in most conceptual forest development models. For example, Oliver et al. (1994) concluded second-growth $S$. sempervirens respond well to thinning but potential biological legacy trees were removed. Additionally, uniform spacing was a primary goal which failed to consider the natural structural complexity present in unharvested stands.

The more succession is studied, the more apparent it becomes that an ecosystem's composition and structure is composed of patches in various states of recovery following disturbances of varying types and intensities (Picket \& White 1985). Ecosystem complexity is more a result of the variability of disturbances than of succession itself. 
Therefore, succession and disturbance are intrinsically linked. This phenomenon is recognized in the gap theory of succession.

In forests, small scale disturbances can cause gaps in the forest canopy (Watt 1947; Whitmore 1978; Brokaw 1985; Busing \& Fujimori 2009). The areas of these gaps can range in size, with the death of individual branches or trees producing small gaps and more catastrophic events such as large-scale blow downs causing vast openings in the canopy (Yamamoto 1992). These gaps allow sunlight to penetrate the forest floor in areas which have not been exposed to the sun for extended periods of time. In these areas, succession occurs on a small-scale allowing understory species to grow and fill the gap (Brokaw 1985). In older forests, larger gaps occur as a result of trees fall events that include multiple, or bigger, trees. Gap phase succession leads to multi-aged heterogeneous stands (Bugmann 2001). S. sempervirens forest are resilient to many natural disturbances, in these forests, windfall is the primary driver behind gap phase succession (Sawyer et al. 2000a).

\section{Active Management}

Restoration of forest ecosystems through active management has been on the rise in recent decades with projects encompassing stream restorations, non-native species removal, native plant propagation, and the removal of degraded roads. To influence the return of salmonid species, active management techniques have been deployed to restore stream characteristics (Roni et al. 2002). These projects focus on the reestablishment of large woody debris and other stream features that have been removed through various human activities (Roni et al. 2002). Active management has also been successful in the 
removal of old logging roads to reduce sedimentation and impacts to nearby waterways (Harr \& Nichols 1993). Mechanical removal of invasive species has been shown to be beneficial where disturbance to soil has been minimized.

More recently focus has been placed on the restoration of second-growth forests. These restoration practices are based on competition theory and a linear successional model, primarily focusing on restoring stand structural characteristics typically associated with old-growth forests (Hanover \& Russell 2018). These projects use the stand development theory as their guiding principal, and hope to put forests on the fast track to the complex forest stage by using mechanical thinning to skip over the stem exclusion period. Research suggests that active management, in the form of forest thinning, has the ability to increase growth rate of residual trees (O'Hara et al. 2010; Jones \& O'Hara 2012; Mantgem et al. 2017; Teraoka et al. 2017), though effects on forest communities as a whole have not been well studied.

For forest types where historic natural stand replacing events did not occur, active management does not work well on a community scale. Research in these forests has shown non-native species richness is greater on managed plots (Scherer et al. 2000; Battles et al. 2001; Metlen \& Fiedler 2006; Burke et al. 2008). In addition, commonly associated understory species found on naturally recovering sites are not often found on managed sites (Battles et al. 2001). Late successional species appear to be particularly vulnerable (Halpern \& Spies 1995; Nelson et al. 2007; Burke et al. 2008).

For $S$. sempervirens forests the effects of using silviculture as a restoration technique are not fully understood. S. sempervirens has the ability to sprout vegetatively, which 
could potentially be counterintuitive to restoration goals of reducing density if $S$. sempervirens are included in the thinning treatment (O’Hara et al. 2015). A study looking specifically at density following thinning found density increased on all thinned plots four years after treatment. A simulated growth study found that several re-entries would be required to achieve old-growth densities (Berrill et al. 2013). In addition, it was concluded that restoration goals would not be met under any of the thinning prescriptions tested in a 300-year time frame (Berrill et al. 2013). Another goal of restorative thinning in S. sempervirens forests is to shift species composition towards S. sempervirens, however Chittick and Keyes (2004) found thinning fell short of meeting this goal.

The effect of using silviculture as a restoration technique on herbaceous understory species associated within $S$. sempervirens forests is of particular concern. Many of these species are sensitive to logging, and may provide a metric for assessing the recovery of $S$. sempervirens forest communities as a whole (Loya \& Jules 2008; Russell \& Michels 2011). In addition, much of the plant diversity in S. sempervirens forests is found in the understory (Gilliam 2007). The decline of redwood associated understory species, such as $A$. caudatum, C. andrewsiana, L. latifolia, M. racemosum, O. oregana, $P$. munitum, $P$. hookeri, T. ovatum, and $V$. sempervirens following logging events has been well documented, and has been correlated to other forest metrics such as reduction in canopy cover and the establishment of non-native species (Meier et al. 1995; Gilliam 2007; Loya \& Jules 2007; Russell 2009; Russell \& Michels 2011; Russell et al. 2014; Peterson \& Russell 2017). Research suggests that the abundance and cover of understory associated species can be slow to recover (Loya \& Jules 2007; Russell \& Michels 2011). In 
addition, individual species appear to recover at different rates, based on varying sensitivities to logging. Keyes and Teraoka (2014), for example, found that total understory cover in old-growth and second-growth did not vary significantly, however key redwood associates, including $O$. oregana and $T$. ovatum, were significantly higher in old-growth stands. Keyes and Teraoka (2014) argue that their results support the notion of active restoration in the form of variable density thinning, but do not consider the potential impacts of additional logging operations on natural processes of forest recovery. It is essential to understand the ability of forest understory to recover following timber harvest when considering the implementation of silvicultural practices as a restoration technique (Thomas et al. 1999; Ellum 2009).

\section{Problem Statement}

When using active management techniques to restore an ecosystem, it is critical to consider potential benefits, as well as impacts associated with implementation, especially when using the same tools that created the original disturbance (Russell et al. 2014). Recent studies suggest that active management, through the use of silvicultural manipulation, is a potentially effective option to help second-growth S. sempervirens stands achieve structure and function which more closely resembles old-growth on a shorter time scale (O’Hara et al. 2010; Teraoka 2012; Teraoka et al. 2016). However, these studies assessed the effectiveness of these treatments using silvicultural metrics such as stand density and the growth rate of individual trees, but did not adequately quantify the effects on herbaceous understory species. The objective of this study was to determine how understory species composition and richness vary between restorative 
treatments, including recovering second-growth $S$. sempervirens stands without mechanical thinning, and stands that have been thinned for the expressed purpose of promoting old-growth characteristics.

\title{
Chapter 2: Manuscript
}

\begin{abstract}
Restoration of late seral features in second-growth Sequoia sempervirens forests is an important management concern, as so little of the original old-growth remains. The abundance of herbaceous species provides a metric for assessing recovery in these forests where associated understory plants are adapted to closed canopy conditions. Data were collected using a stratified random sampling design across three treatments: mechanically thinned second-growth, un-thinned second-growth, and old-growth reference stands. Pairwise permutational multivariate analysis of variance indicated greater abundance and diversity of native herbs in old-growth and un-thinned second-growth compared to thinned stands, as well as higher measures of canopy cover, basal area, and dominance of S. sempervirens. Thinned plots exhibited lower stand density than un-thinned stands but also higher abundance of non-native herbs. Non-metric multidimensional scaling suggested that un-thinned sites were more similar to old-growth than thinned sites in regard to understory composition and abundance, and indicator species analysis returned a suit of indicator species shared between un-thinned plots and old-growth plots while thinned plots shared one indicators with old-growth. In addition, both old-growth and un-thinned second growth sites were dominated by residual species, while thinned plots were dominated by invader species. These results suggest that while mechanical thinning
\end{abstract}


of second-growth $S$. sempervirens stands may provide temporary effects to stand structure and composition, these treatments do not support the recovery of late seral understory species.

Key Words: natural recovery, active management, understory, old-growth, late seral Introduction

Active restoration of previously logged forests using silvicultural tools is a growing trend. This approach employs stand thinning techniques to meet targets related to tree density and overstory species composition, with the goal of enhancing the development of old-growth characteristics (O’Hara et al. 2010; Jones \& O’Hara 2012; Mantgen et al. 2017; Teraoka et al. 2017). A variety of characteristics have been associated with "oldgrowth”, defined as forests without a significant logging history (Bolsinger et al. 1993; Frelich \& Reich 2003; Bauhus et al. 2009). Large old trees and relatively low tree density are commonly referenced, along with stand complexity, and the prevalence of snags, large woody debris, and associated wildlife and understory plant assemblages (Van Pelt \& Franklin 2000; Busing \& Fujimori 2009; Spies \& Duncan 2009).

The use of thinning as a restoration tool in coast redwood forests has primarily focused on reducing stand density, increasing the incremental growth of individual trees, and increasing the relative dominance of $S$. sempervirens in second-growth stands. Evidence suggests that these treatments are effective for reducing stand density in the short run, and for increasing the growth rate of individual trees (O'Hara 2010). The longterm response to restorative thinning of stand structure and composition in $S$. sempervirens forests is less clear, however. S. sempervirens has the tendency to sprout 
vegetatively following thinning treatments, which is counterproductive to the restoration goal of reducing stand density, especially when S. sempervirens itself is included in the thinning treatment (O’Hara et al. 2015). For example, tree density was found to increase only four years after restorative thinning, rather than decrease, as a result of vegetative sprouting (O'Hara et al. 2010). Repeated thinning treatments are required to retain density targets, and even with these re-entries, restoration goals are projected not to be met within a three-century time frame (Berrill et al. 2013). Where S. sempervirens stands have experienced a shift in composition away from redwood, due to seeding of other species following logging or due to successional pressures, mechanical removal of nonredwood species may be an attractive option. However, variation of canopy openings through thinning can encourage competing species, and thinning treatments can fall short of meeting compositional goals (Chittick \& Keyes 2004).

Commonly, the metrics used to assess forest recovery following thinning are the same variables that were manipulated in the treatment (i.e. stand structure and composition) (O’Hara et al. 2010; Teraoka 2012; Teraoka et al. 2017). Assessment of additional metrics that can serve as response variables could provide a clearer understanding of the effectiveness of restoration treatments on the forest community as a whole. Measurement of understory plant species as a metric for forest recovery is particularly attractive, as understory species are dependent on canopy conditions, and their abundance may be independent of stand structure variables.

Understory species response to silvicultural treatment has been assessed in a variety of forest types. Active management has been shown to increase community 
heterogeneity without having a strong effect on understory vegetation in fire adapted pine forests (Dodson \& Peterson 2010). Using mechanical thinning to reduce density in hardwood forests has been achieved without significant effects on the herbaceous layer (Jenkins \& Parker 1999; Gilliam 2002; Kern 2006). In addition, active management had no significant effect on diversity and abundance of spring forest herbs in the southwestern deciduous forest of Ontario (Falk et al. 2008).

Understory species are not as resilient in coastal coniferous forests, such as the Sequoia sempervirens dominated coast redwood forest, where natural stand replacing events are rare, and associated understory species are adapted to a regime of high moisture and low solar radiation (Limm et al. 2009). Many of the herbaceous understory species in this forest type are known to be sensitive to logging (Loya \& Jules 2008; Russell \& Michels 2011). The decline of redwood associated understory species such as Oxalis oregana, Trillium ovatum, and Viola sempervirens following logging events has been well documented (Russell 2020), and has been correlated to other forest metrics such as reduction in canopy cover and the establishment of non-native species (Meier et al. 1995; Kahmen \& Jules 2005; Gilliam 2007; Loya \& Jules 2007; Russell 2009; Russell \& Michels 2011). Research suggests that the abundance and cover of many understory associated species can be slow to recover following silvicultural treatments, with individual species recovering at different rates based on varying sensitivities to logging (Loya \& Jules 2007; Russell \& Michels 2011). Keyes and Teraoka (2014), for example, found that total understory cover in old-growth and second-growth stands did not vary 
significantly; however, key redwood associates, including $O$. oregana and $T$. ovatum, were significantly higher in old-growth stands.

The recovery of herbaceous understory species associated with S. sempervirens forests may provide a metric of forest recovery more closely tied to ecosystem recovery as a whole than silvicultural metrics, as much of the plant diversity in the S. sempervirens forest is found in the understory, and the understory is dependent on canopy conditions (Gilliam 2007). With a better understanding of the effects of silvicultural thinning as a restoration tool on the plant community as a whole, land managers can make more informed decisions on the restoration of second-growth S. sempervirens forests. The objective of this study was to determine how understory species composition and richness vary between restorative treatments including recovering second-growth $S$. sempervirens stands without mechanical thinning, and stands that have been thinned for the expressed purpose of promoting old-growth characteristics.

\section{Methods}

\section{Study System}

Data were collected in the Redwood Creek watershed of Redwood National Park, located in Humboldt County, California. Redwood National Park consists of 53,412 ha of old-growth and recovering second-growth Sequoia sempervirens forests in the northern part of the coast redwood range. The Redwood Creek Watershed includes stands with a variety of management histories, including un-cut old-growth, un-thinned second-growth, and thinned second-growth S. sempervirens stands, providing the basis for site selection. Areas of the watershed that were clear-cut in the last century provided 
57-75-year-old second-growth stands large enough to sample, while avoiding edge effects of varying ecosystem types and age class boundaries (National Park Service 2008).

The vegetation in the area is characteristic of that found in the northern range of $S$. sempervirens, and consists of stands dominated by S. sempervirens and Pseudotsuga menziesii with Alnus rubra (Red alder), Arbutus menziesii (Pacific madrone), Chrysolepis chrysophylla (Golden chinquapin), Notholithocarpus densiflorus (Tanoak), P. menziesii, S. sempervirens and Thuja plicata (Western red cedar) making up the subcanopy. Common herbaceous understory species include Asuram caudatum, Lysimachia latifolia, Oxalis oregana, Prosartes hookeri, Polystichum munitum, Pteridium aquilinum var. pubescens (Bracken fern), Trillium ovatum, Rhododendron macrophyllum (Pacific rhododendron), and Viola sempervirens.

Climate in the study area is characterized by mild temperatures, wet winters, and foggy summers. Annual precipitation ranges from $178-254 \mathrm{~cm}$ with average annual temperatures ranging from $10^{\circ}-13^{\circ} \mathrm{C}$. Seasonal fluctuations in air temperature are limited by a moderately strong marine influence. Soils in the study area are very deep well drained Coppercreek-Slidecreek-Tectah soils derived from sandstone and mudstone.

Study Sites. Three treatments were studied within the northern portion of the Redwood Creek Watershed in Redwood National Park including a thinned treatment, an un-thinned treatment, and an old-growth treatment, with three study sites located within each treatment. 
Study sites for the thinning treatment were located within the South Fork of Lost Man Creek Management area, which is composed of 688 ha of second-growth S. sempervirens forest that was clear-cut between 1954 and 1962 (Teraoka 2012). Four to eight remnant S. sempervirens trees were left on site as seed trees to regenerate naturally in accordance with the California Forest Practice Act of 1945. Additionally, the area was aerially reseeded with P. menziesii at a rate of 4.5-5.6 kg/ha (Teraoka 2012). Aerial seeding led to increased stand density, and a compositional shift from S. sempervirens to P. menziesii (NPS 2008; Teraoka 2012; NPS 2014). The current management goals in this area are to reduce density, shift composition towards $S$. sempervirens, and influence the recruitment of old forest features (NPS 2008).

To meet management goals several thinning treatments were implemented between 2009 and 2011. This study focused on the thin remove treatment that was implemented on sites where the slope did not exceed 30\% (NPS 2008; NPS 2014). In these treatments a low thinning was used to reduce the basal area by 40\% (NPS 2008; Teraoka 2012; NPS 2014). Merchantable wood was removed and sold; all non-merchantable wood was removed and sent to a cogeneration powerplant (Teraoka 2012). Trees were limbed on site and all slash was scattered across the treatment in depths no greater than $61 \mathrm{~cm}$. Eight separate units were treated under the thin remove protocol for a total of 146 ha treated (NPS 2014). Harvesting of P. menziesii took precedence, with removal of $S$. sempervirens being the last species removed to meet basal area reduction targets (NPS 2008; NPS 2014). During thinning operations, approximately $42 \mathrm{~km}$ of former skid roads, 40 former landings, and $24 \mathrm{~m}$ of administrative roads were rehabilitated, but no 
new roads were constructed (NPS 2008). Following thinning treatments, all haul roads and landings were removed under the park watershed restoration program (NPS 2008).

Timber harvest maps, topographic maps, geological data, and historic land use data were used to select replicated study sites in old-growth and second-growth stands. Sites included in this study were historically dominated by S. sempervirens, and had similar soil types, slope, and elevational ranges (Table 1). In addition, second-growth sites included in this study were all previously seed tree cut and aerial seeded with $P$. menziesii following harvest between 1945 and 1962.

Table 1. Site characteristics for nine sites within three treatments at Redwood National Park.

\begin{tabular}{lccccc}
\hline Site & Treatment & Plots & Harvest Year & Elevation Range & Slope Range \\
\hline Lady Bird Johnson & old-growth & 10 & - & $395-440 \mathrm{~m}$ & $0-21^{\circ}$ \\
Berry Glenn & old-growth & 10 & - & $370-424 \mathrm{~m}$ & $1-26^{\circ}$ \\
Ball Hills & old-growth & 10 & - & $450-495 \mathrm{~m}$ & $1-21^{\circ}$ \\
Harding Mill & un-thinned & 10 & 1945 & $220-406 \mathrm{~m}$ & $5-30^{\circ}$ \\
Geneva & un-thinned & 10 & 1954 & $280-415 \mathrm{~m}$ & $7-20^{\circ}$ \\
Holter Ridge & un-thinned & 10 & 1962 & $492-532 \mathrm{~m}$ & $2-20^{\circ}$ \\
Unit A & thinned & 10 & 1954 & $632-687 \mathrm{~m}$ & $1-20^{\circ}$ \\
Unit B & thinned & 10 & 1954 & $595-665 \mathrm{~m}$ & $1-24^{\circ}$ \\
Unit L & thinned & 10 & 1954 & $549-613 \mathrm{~m}$ & $2-26^{\circ}$ \\
\hline
\end{tabular}

\section{Data Collection}

Ten 20 m diameter circular tree plots were randomly selected within each study site for a total of 90 plots. Plot size and sampling intensity was based on previous literature in this ecosystem type (Loya \& Jules 2007; Russell \& Michels 2011; Russell et al. 2014; Petersen \& Russell 2017). Each plot was located a minimum of $20 \mathrm{~m}$ from neighboring plots, $10 \mathrm{~m}$ from special habitat features, and $200 \mathrm{~m}$ from age class boundaries to limit edge effects (Russell \& Jones 2001). 
Study sites were located in the field using a hand-held GPS unit. Once on site, plot center was determined in the field by first randomizing distance along access trails followed by distance off trail. Direction off trail was alternated between plots. Plot characteristics were recorded at plot center including: canopy cover using a spherical densiometer, slope using a clinometer, aspect using an azimuth compass, and elevation using a handheld GPS. Distance to the nearest stream was measured using ArcGIS. A transect tape was used to measure $20 \mathrm{~m}$ diameter plots $(0.031 \mathrm{ha})$, which is consistent with previous research in this forest type (Loya \& Jules 2007; Michels \& Russell 2010).

The number of stems was recorded for all mature trees $(\mathrm{dbh}>10 \mathrm{~cm})$, sapling sized trees $(\mathrm{dbh}<10 \mathrm{~cm}$, height $>1 \mathrm{~m})$, and seedling size trees $(\mathrm{dbh}<10 \mathrm{~cm}$, height $<1 \mathrm{~m})$. Diameter at breast height (dbh) was recorded for all trees that were taller than one meter in height, and had a dbh greater than $10 \mathrm{~cm}$, using a diameter tape. Diameter at breast height was measured $1.37 \mathrm{~m}$ above the ground on the uphill side of the slope. For trees with multiple stems, dbh was recorded separately for each stem if the split occurred below $1.37 \mathrm{~m}$. All trees with more than $50 \%$ of the trunk located within the plot were recorded. In addition, presence of excessive slash, presence of former roads, and presence of former landings were recorded if they were within the plot boundaries.

To assess understory composition within each plot, all vascular understory species were identified according to the Jepson Manual (Baldwin et al. 2012). Each plot was divided into four quadrants where ocular estimates for absolute percent cover were recorded for each species over the entire plot. Individual quadrant totals were averaged to determine total percent cover for each species over the entire plot. 


\section{Analytical Methods}

To explore differences between treatment types, SPSS version 26 was used to run descriptive comparisons for each treatment. Kruskal Wallis and ANOVA tests were used to test for significant differences between treatments for all physiographic variables (elevation, slope, and proximity to stream), canopy variables (canopy cover, basal area, tree density, and species dominance), and understory variables (cover and richness of native herbaceous species, shrub species, and non-native species). All pairwise comparisons were made using Tukey’s HSD for normal data, and Dunn's multiple comparisons test with Bonferroni adjustment were used for data that were not normally distributed. A multivariate approach was used to further explore differences using RStudio version 1.2 statistical software (RStudio Team 2015).

To explore understory compositional differences, non-metric multi-dimensional scaling (NMDS) with Bray Curtis distance measure was conducted using the metaMDS function in the vegan package (Legendre \& Legendre 2012; Oksanen 2015; Oksanen et al. 2019). To improve multivariate fit and for ease of interpretation, only species which occurred on greater than $5 \%$ of plots were included in the ordination matrix. The envfit function with an $\mathrm{R}^{2}$ cutoff of 0.3 was used to explore correlation between response variables and understory community composition (Loya \& Jules 2008; Oksanen 2015). The final species matrix measured 90 plots by 43 species. The final matrix of response variables measured 90 plots by 76 variables.

Differences in understory composition between the three treatments were assessed using permutational multivariate analysis of variance (PerMANOVA). PerMANOVA 
was carried out using the Adonis function in the Vegan package (Oksanen 2015; Oksanen et al. 2019). All pairwise comparisons were made using the Bonferroni adjustment to determine which treatments differed.

To determine if individual species were associated with the different treatments, an indicator species analysis (ISA) was conducted using the Multipatt function in the indicspecies package (De Cáceres \& Legendre 2009; De Cáceres 2013). ISA uses relative frequency and relative abundance within groups to assign an indicator value between 0-1 to each species (Dufrene \& Legendre 1997). To better understand if there was any overlap between treatment types and indicator species, ISA was used with combinations of site groups (De Cáceres et al. 2010). Spearman's rank correlation test with a $\mathrm{r}$ cutoff of 0.6 was used to assess correlations between indicator species and stand parameters.

\section{Results}

Kruskal Wallis tests indicated significant variations between treatments in regard to forest structure, as well as the composition and distribution of understory species (Table 2). A total of 67 vascular plant species, were identified in the 90 plots sampled, including five tree species, 15 woody shrub species, 42 herbaceous species, and 5 non-native species (Appendix A).

Tree density was significantly lower on old-growth plots than both thinned and unthinned plots (Table 2, Figure 1). Canopy cover was the greatest on old-growth plots with un-thinned plots statistically similar to old-growth while thinned plots did vary. No similiarities were found between treatments for total basal area, with thinned plots 
exhibitting the greatest basal area and old-growth plots the lowest (Table 2). Sequoia

sempervirens dominated on old-growth plots while Pseudotsuga menziesii was the

dominate tree species found on both thinned and un-thinned plots.

Table 2. Mean, standard error (S.E.), and $p$-value for each physiographic metric, canopy metric, and understory metric measured within each treatment.

\begin{tabular}{|c|c|c|c|c|}
\hline & OG mean (S.E.) & UT mean (S.E.) & T mean (S.E.) & p-value \\
\hline \multicolumn{5}{|l|}{ Physiographic metrics } \\
\hline Elevation $(\mathrm{m})$ & $432.27(6.64)^{\mathrm{a}}$ & $384.63(16.72)^{\mathrm{a}}$ & $647.13(7.98)^{\mathrm{b}}$ & $<0.0001^{*}$ \\
\hline Slope $(\%)$ & $5.17(0.64)^{\mathrm{a}}$ & $13.3(1.20)^{\mathrm{b}}$ & $4.47(0.54)^{\mathrm{a}}$ & $<0.0001^{*}$ \\
\hline Distance to stream (m) & $897.73(26.78)^{b}$ & $532.87(63.25)^{\mathrm{a}}$ & $465.20(14.39)^{\mathrm{a}}$ & $<0.0001^{*}$ \\
\hline \multicolumn{5}{|l|}{ Canopy metrics } \\
\hline Canopy cover (\%/plot) & $79.2(1.55)^{\mathrm{a}}$ & $78.07(1.44)^{\mathrm{a}}$ & $64.3(2.30)^{\mathrm{b}}$ & $<0.001^{*}$ \\
\hline Basal area $\left(\mathrm{m}^{2} / \mathrm{ha}\right)$ & $270.55(30.32)^{\mathrm{a}}$ & $66.77(4.29)^{\mathrm{b}}$ & $42.39(3.20)^{\mathrm{c}}$ & $<0.001 *$ \\
\hline Tree $>10 \mathrm{~cm}$ density $($ stems $/$ ha $)$ & $274.81(36.90)^{\mathrm{a}}$ & $804.26(70.75)^{\mathrm{b}}$ & $662.08(52.06)^{\mathrm{c}}$ & $<0.001 *$ \\
\hline SESE dominance $(\%)$ & $64.21(5.67)^{\mathrm{a}}$ & $45.57(4.54)^{\mathrm{a}}$ & $15.7(3.73)^{\mathrm{b}}$ & $<0.001 *$ \\
\hline PSME dominance $(\%)$ & $21.35(4.90)^{\mathrm{a}}$ & $38.46(4.61)^{\mathrm{a}}$ & $67.54(4.58)^{b}$ & $<0.001 *$ \\
\hline \multicolumn{5}{|l|}{ Understory metrics } \\
\hline Total native cover ( $\% /$ plot $)$ & $51.27(2.65)^{\mathrm{a}}$ & $27.63(2.03)^{b}$ & $12.17(2.24)^{\mathrm{c}}$ & $<0.001^{*}$ \\
\hline Native herb cover $(\% / \mathrm{plot})$ & $19.02(2.88)^{\mathrm{b}}$ & $12.07(2.46)^{\mathrm{a}}$ & $9.07(2.21)^{\mathrm{a}}$ & $0.002 *$ \\
\hline Native shrub cover $(\% /$ plot $)$ & $32.25(2.39)^{\mathrm{a}}$ & $15.57(2.17)^{\mathrm{b}}$ & $3.1(0.70)^{\mathrm{c}}$ & $<0.001^{*}$ \\
\hline Non-native cover (\%/plot) & $0(0)^{\mathrm{a}}$ & $0.01(0.01)^{\mathrm{a}}$ & $0.11(0.03)^{\mathrm{b}}$ & $<0.001^{*}$ \\
\hline Total native richness (sp/plot) & $17.13(0.71)^{b}$ & $11.37(0.90)^{\mathrm{a}}$ & $7.70(0.64)^{\mathrm{a}}$ & $<0.001 *$ \\
\hline Native herb richness (sp/plot) & $11.9(0.66)^{\mathrm{ab}}$ & $7.03(0.71)^{\mathrm{a}}$ & $5.83(0.59)^{b}$ & $<0.001^{*}$ \\
\hline Native shrub richness (sp/plot) & $5.47(0.26)^{\mathrm{a}}$ & $4.3(0.31)^{\mathrm{a}}$ & $2.40(0.23)^{\mathrm{b}}$ & $<0.001 *$ \\
\hline Non-native richness (sp/plot) & $0(0)^{\mathrm{a}}$ & $0.03(0.03)^{\mathrm{a}}$ & $0.5(0.13)^{\mathrm{b}}$ & $<0.001 *$ \\
\hline
\end{tabular}

The alphabetic coding shows the results of pairwise comparisons between treatment types for each metric.

Corresponding letters indicate lack of statistically significant differences (adjusted $p>0.05$ ). For pairwise comparison, p-values were adjusted using the Bonferroni correction for multiple tests. $\mathrm{OG}=$ old-growth, $\mathrm{UT}=$ un-thinned, $\mathrm{T}=\mathrm{thinned}$. $\mathrm{SESE}=$ Sequoia sempervirens, $\mathrm{PSME}=$ Pseudotsuga menziesii. 


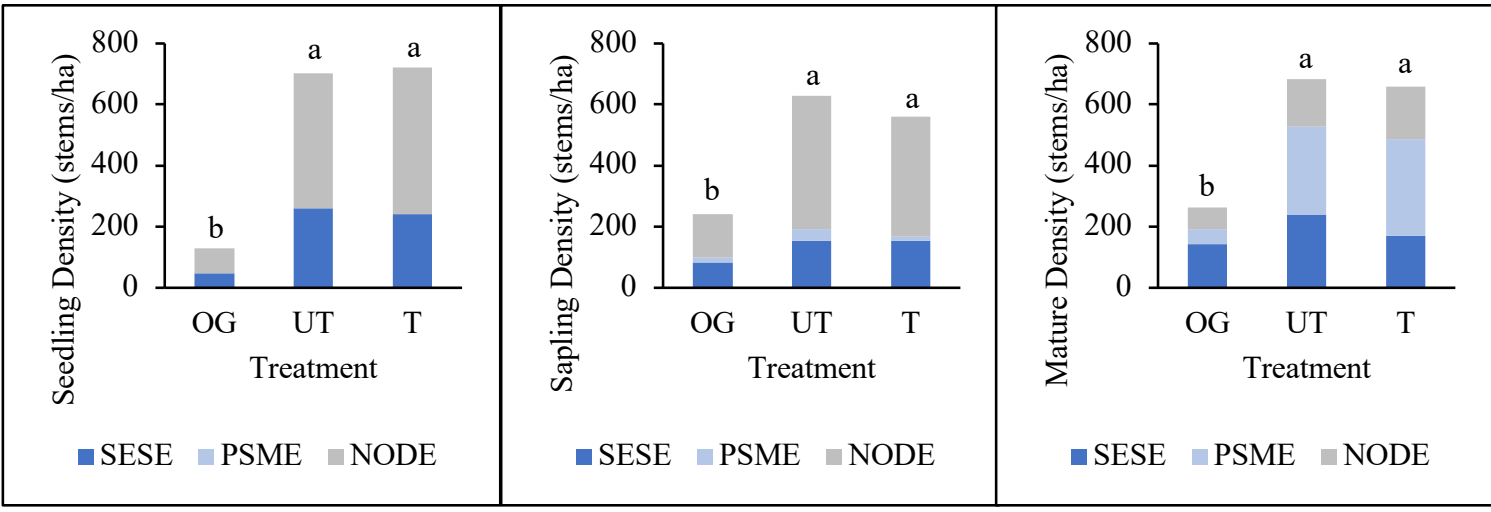

Figure 1. Average size class tree density per species on old-growth plots (OG), un-thinned plots (UT), and thinned plots $(\mathrm{T})$ in Redwood National Park. Seedling density includes all stems that were less than $10 \mathrm{~cm}$ dbh and less than 1 meter in height. Sapling density includes all stems that were less than $10 \mathrm{~cm}$ dbh and greater than 1 meter in height. Mature density includes all stems that were greater than $10 \mathrm{~cm} \mathrm{dbh}$. The alphabetic coding indicates the results of pairwise comparisons between treatment types for each metric. Corresponding letters indicate lack of statistical significance (adjusted $p>0.05$ ). Species codes are as follows: SESE $=$ Sequoia sempervirens, PMSE $=$ Pseudotsuga menziesii, NODE = Notholithocarpus densiflorus.

Old-growth plots exhibited the highest native cover and richness for both herbs and shrubs, while thinned plots had the lowest (Figure 2). Thinned plots varied significantly from old-growth plots for all response variables measured, whereas, un-thinned plots were similar to old-growth plots in non-native cover, non-native richness, and native shrub cover. Non-native cover was the greatest on thinned plots and non-existent on oldgrowth plots (Table 2).
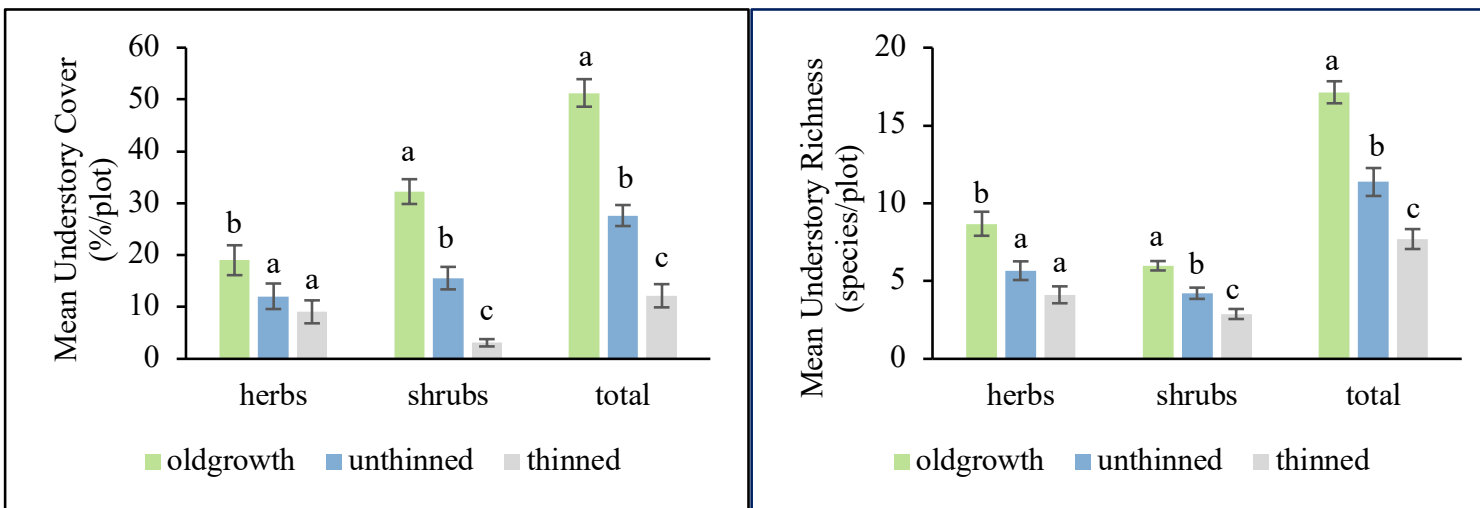

Figure 2. Mean percent cover and mean species richness per plot for native herbaceous vascular plant understory, native shrub understory and total native understory within the three treatment types in Redwood National Park. Error bars show \pm 1 standard error. The alphabetic coding shows the results of pairwise comparisons between treatment types for each subset of data. Corresponding letters within each data subset indicate lack of a statistical difference $(p>0.05)$ for that subset. 
NMDS ordination of the understory cover data returned a three-dimensional solution accounting for $98.1 \%$ of the variation with a stress value of 0.138 . Two convergent solutions were found after 98 attempts (Figure 3). The three treatments formed distinct groups with overlap occurring between old-growth and un-thinned, as well as un-thinned and thinned. While there was no overlap between the thinned and old-growth treatments. PerMANOVA supported ordination findings $\left(\mathrm{F}_{(2,87)}=11.652, p=0.005\right)$. Pairwise comparisons among old-growth and un-thinned plots $(p=0.015)$, old-growth and thinned plots $(p=0.003)$, and thinned and un-thinned plots $(p=0.003)$ indicated significant difference in composition between treatments.

Several correlations were found between ordination scores and response variables. Native richness $(\mathrm{r}=0.68, p<0.001)$ and native cover $(\mathrm{r}=0.61, p<0.001)$ were positively correlated along axis two (NMDS2) in the direction of old-growth plots, whereas, non-native richness $(\mathrm{r}=0.57 p<0.001)$ was negatively correlated along axis two in the direction of the thinned plots. Trillium ovatum cover $(\mathrm{r}=0.64, p<0.001)$, Prosartes hookeri cover $(\mathrm{r}=0.62, p<0.001)$, Polystichum munitum cover $(\mathrm{r}=0.70, p<$ $0.001)$, and Oxalis oregana cover $(\mathrm{r}=0.63, p<0.001)$ were all positively correlated along axis two in the direction of old-growth plots. Additionally, Notholithocarpus densiflorus seedling density $(\mathrm{r}=0.61, p<0.001)$ and non-native richness $(\mathrm{r}=0.3253, p<$ 0.001 ) were negatively correlated along axis two in the direction of thinned plots. 


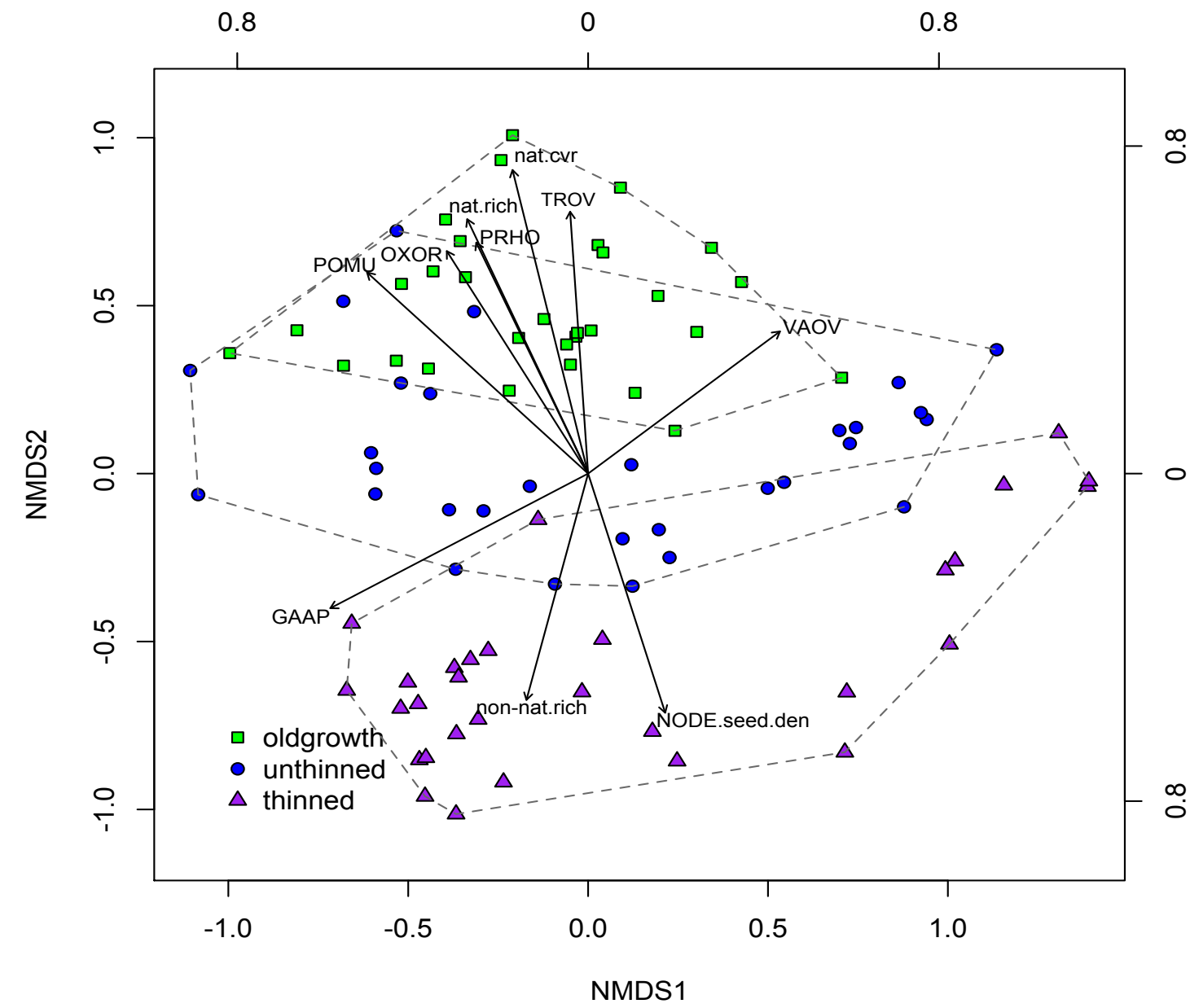

Figure 1. Nonmetric Multidimensional Scaling ordination of the understory composition in 90 plots across three treatments in Redwood National Park. The symbols represent plots in each treatment type oriented relative to community composition similarity. The vectors show the strength and direction of correlations between variables and ordination scores. Vectors are as follows: Polystichum munitum cover (POMU) $\mathrm{R}^{2}=0.4954$, Trillium ovatum cover (TROV) $\mathrm{R}^{2}=0.4105$, Oxalis oregana cover $(\mathrm{OXOR}) \mathrm{R}^{2}=0.3994$, Prosartes hookeri cover $(\mathrm{PRHO})$ $\mathrm{R}^{2}=0.3832$, Vaccinium ovatum cover $(\mathrm{VAOV}) \mathrm{R}^{2}=0.3120$, Gaultheria shallon cover $(\mathrm{GASH}) \mathrm{R}^{2}=0.2910$, Gallium aparine cover (GAAP) $\mathrm{R}^{2}=0.4536$, Notholithocarpus densiflorus seedling density (NODE.seed.den) $\mathrm{R}^{2}=0.3724$, percent cover of native species (native.cvr) $\mathrm{R}^{2}=0.5801$, total native richness (nat.rich) $\mathrm{R}^{2}=0.4620$, and non-native richness (non-nat.rich) $\mathrm{R}^{2}=0.3253$.

When herbaceous understory was further categorized into an invader species group

and a residual species group, as described by Halpern (1989), significant differences were

found between treatments. Thinned plots were dominated by invader species while old-

growth and un-thinned plots were donminated by residual species (Figure 4). At the 
species level, cover of P. munitum, Pteridium aquilinum var. pubescens, Dropteris arguta (Coastal wood fern), and Aralia californica (Elk clover) on un-thinned plots was similar to that which was found on old-growth plots. While cover of other residual species was significantly less on both thinned and un-thinned plots (Table 3).

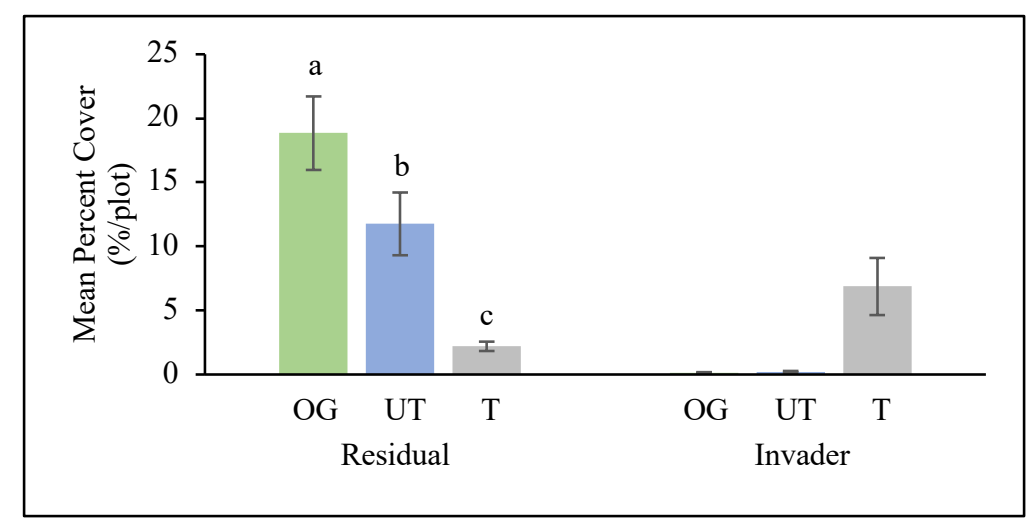

Figure 2. Mean percent cover per plot for residual and invader herbaceous vascular plant understory within the three treatment types in Redwood National Park. Error bars show \pm 1 standard error. The alphabetic coding shows the results of pairwise comparisons between treatment types for each subset of data. Corresponding letters within each data subset indicate lack of a statistical difference $(p>0.05)$ for that subset. $\mathrm{OG}=$ old-growth, $\mathrm{UT}=$ un-thinned, $\mathrm{T}=$ thinned 
Table 3. Significant findings of Kruskal Wallis H Tests comparing percent cover of individual herbaceous species between treatments.

\begin{tabular}{|c|c|c|c|c|c|}
\hline & type & OG mean (S.E.) & UT mean (S.E.) & T mean (S.E.) & p-value \\
\hline Blechnum spicant & $\mathrm{R}$ & $0.033(0.013)^{\mathrm{ab}}$ & $0.096(0.044)^{\mathrm{a}}$ & $0^{\mathrm{b}}$ & 0.012 \\
\hline Polystichum munitum & $\mathrm{R}$ & $10.842(2.176)^{\mathrm{a}}$ & $9.088(2.094)^{\mathrm{a}}$ & $0.217(0.055)^{\mathrm{b}}$ & $<0.0001$ \\
\hline $\begin{array}{l}\text { Pteridium aquilinum var. } \\
\text { pubescens }\end{array}$ & $\mathrm{R}$ & $0.008(0.006)^{\mathrm{a}}$ & $0.038(0.016)^{\mathrm{a}}$ & $0.467(0.130)^{\mathrm{b}}$ & $<0.0001$ \\
\hline Dryopteris arguta & $\mathrm{R}$ & $0.292(0.114)^{\mathrm{a}}$ & $0.283(0.155)^{\mathrm{a}}$ & $0^{\mathrm{b}}$ & 0.003 \\
\hline Trillium ovatum & $\mathrm{R}$ & $0.429(0.040)^{\mathrm{a}}$ & $0.183(0.032)^{\mathrm{b}}$ & $0.008(0.006)^{\mathrm{c}}$ & $<0.0001$ \\
\hline Cardamine californica & $\mathrm{R}$ & $0.367(0.047)^{\mathrm{b}}$ & $0.138(0.040)^{\mathrm{a}}$ & $0.050(0.046)^{\mathrm{a}}$ & $<0.0001$ \\
\hline Goodyera oblongifolia & $\mathrm{R}$ & $0.100(0.035)^{\mathrm{a}}$ & $0.008(0.006)^{\mathrm{b}}$ & $0.029(0.013)^{\mathrm{ab}}$ & 0.040 \\
\hline Anemone deltoidea & $\mathrm{R}$ & $0.146(0.046)^{\mathrm{b}}$ & $0^{\mathrm{a}}$ & $0^{\mathrm{a}}$ & $<0.0001$ \\
\hline Asuram caudatum & $\mathrm{R}$ & $0.250(0.152)^{\mathrm{b}}$ & $0.038(0.435)^{\mathrm{a}}$ & $0^{\mathrm{a}}$ & 0.003 \\
\hline Oxalis oregana & $\mathrm{R}$ & $4.717(0.849)^{\mathrm{b}}$ & $0.717(0.435)^{\mathrm{a}}$ & $0.308(0.111)^{\mathrm{a}}$ & $<0.0001$ \\
\hline Maianthemum racemosum & $\mathrm{R}$ & $0.183(0.045)^{\mathrm{b}}$ & $0^{\mathrm{a}}$ & $0^{\mathrm{a}}$ & $<0.0001$ \\
\hline Prosartes hookeri & $\mathrm{R}$ & $0.196(0.029)^{\mathrm{b}}$ & $0.054(0.022)^{\mathrm{a}}$ & $0^{\mathrm{a}}$ & $<0.0001$ \\
\hline Adenocaulon bicolor & $\mathrm{R}$ & $0.092(0.021)^{\mathrm{b}}$ & $0^{\mathrm{a}}$ & $0^{\mathrm{a}}$ & $<0.0001$ \\
\hline Aralia californica & $\mathrm{R}$ & $0.088(0.042)^{\mathrm{a}}$ & $0.167(0.146)^{\mathrm{a}}$ & $0^{\mathrm{b}}$ & 0.039 \\
\hline Osmorhiza berteroi & $\mathrm{R}$ & $0.063(0.021)^{\mathrm{b}}$ & $0.021(0.012)^{\mathrm{a}}$ & $0^{\mathrm{a}}$ & 0.003 \\
\hline Whipplea modesta & I & $0.033(0.013)^{\mathrm{a}}$ & $0.121(0.062)^{\mathrm{ab}}$ & $2.742(1.518)^{\mathrm{b}}$ & 0.030 \\
\hline Lathyrus vestitus & I & $0.071(0.023)^{\mathrm{ab}}$ & $0.013(0.009)^{\mathrm{a}}$ & $4.033(1.845)^{\mathrm{b}}$ & 0.008 \\
\hline
\end{tabular}

Species type, mean percent cover, standard error (S.E.), and p-value for each herbaceous understory species which occurred on $>5 \%$ of plots. The alphabetic coding indicates the results of pairwise comparisons between treatment types for each metric. Corresponding letters indicate lack of statistical significance (adjusted $\mathrm{p}>0.05$ ). For pairwise comparison, $\mathrm{p}$-values were adjusted using the Bonferroni correction for multiple tests. $\mathrm{OG}=$ old-growth, UT=unthinned, $\mathrm{T}=$ thinned, $\mathrm{R}=$ residual species, $\mathrm{I}=$ invader species.

Indicator species analysis returned a suite of 29 species as indicators for the three treatment types. Ten species were indicators for old-growth, one was an indicator for unthinned, and five were indicators for thinned. Eight species were indicators for both oldgrowth and un-thinned, while thinned and old-growth shared one indicator species (Figure 5, Table 4). All indicator species for old-growth and un-thinned were native species while two of the indicators for thinned were non-native species. Spearman's rank correlation tests found no meaningful correlations between stand parameters and oldgrowth indicator species. However, proximity to stream was found to be correlated with 
P. aquilinum ( $r=0.67)$, A. californica $(r=0.67)$, Oxalis oregana $(r=0.72)$, $P$. hookeri $(r$ $=0.65)$, and Vaccinium parvifolium (Red huckleberry) $(r=0.60)$.

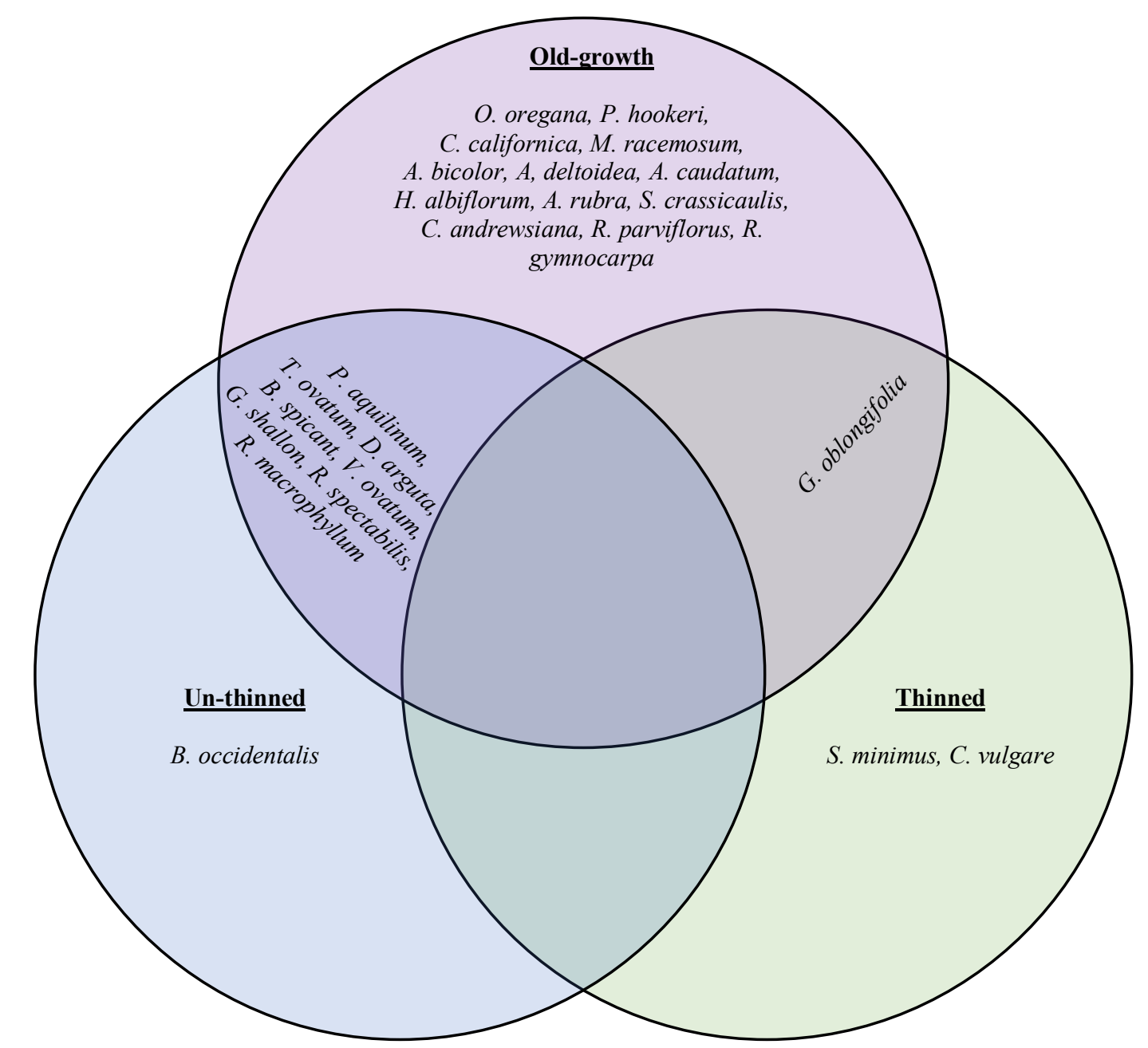

Figure 5. Diagram showing individual treatment indicator species and indicator species shared between treatments. 
Table 4. Results of indicator species analysis for all understory species data collected within the three treatments at Redwood National Park

\begin{tabular}{|c|c|c|c|c|c|}
\hline \multirow[b]{2}{*}{ Species } & \multirow{2}{*}{$\begin{array}{c}\text { Indicator } \\
\text { value }\end{array}$} & \multirow[b]{2}{*}{ p-value } & \multicolumn{3}{|c|}{ Treatment } \\
\hline & & & $\mathrm{OG}$ & UT & $\mathrm{T}$ \\
\hline \multicolumn{6}{|l|}{ Herbs } \\
\hline Polystichum munitum & 0.969 & 0.001 & $\mathrm{X}$ & $\mathrm{X}$ & \\
\hline Trillium ovatum & 0.879 & 0.001 & $\mathrm{X}$ & $X$ & \\
\hline Oxalis oregana & 0.876 & 0.001 & $\mathrm{X}$ & & \\
\hline Prosartes hookeri & 0.775 & 0.001 & $\mathrm{X}$ & & \\
\hline Cardamine californica & 0.772 & 0.001 & $\mathrm{X}$ & & \\
\hline Maianthemum racemosum & 0.753 & 0.001 & $\mathrm{X}$ & & \\
\hline Pteridium aquilinum var. pubescens & 0.697 & 0.001 & & & $\mathrm{X}$ \\
\hline Adenocaulon bicolor & 0.683 & 0.001 & $\mathrm{X}$ & & \\
\hline Whipplea modesta & 0.641 & 0.006 & & & $\mathrm{X}$ \\
\hline Lathyrus vestitus & 0.599 & 0.005 & & & $\mathrm{X}$ \\
\hline Anemone deltoidea & 0.577 & 0.001 & $\mathrm{X}$ & & \\
\hline Dryopteris arguta & 0.563 & 0.006 & $\mathrm{X}$ & $\mathrm{X}$ & \\
\hline Blechnum spicant & 0.483 & 0.011 & $\mathrm{X}$ & $\mathrm{X}$ & \\
\hline Asarum caudatum & 0.482 & 0.005 & $\mathrm{X}$ & & \\
\hline Hieracium albiflorum & 0.474 & 0.006 & $\mathrm{X}$ & & \\
\hline Goodyera oblongifolia & 0.468 & 0.041 & $\mathrm{X}$ & & $\mathrm{X}$ \\
\hline Actaea rubra & 0.447 & 0.006 & $\mathrm{X}$ & & \\
\hline Sanicula crassicaulis & 0.447 & 0.006 & $\mathrm{X}$ & & \\
\hline \multicolumn{6}{|l|}{ Shrubs } \\
\hline Vaccinium ovatum & 0.938 & 0.001 & $\mathrm{X}$ & $\mathrm{X}$ & \\
\hline Gaultheria shallon & 0.936 & 0.001 & $\mathrm{X}$ & $\mathrm{X}$ & \\
\hline Vaccinium parviflorum & 0.869 & 0.001 & $\mathrm{X}$ & & \\
\hline Rhododendron macrophyllum & 0.703 & 0.016 & $\mathrm{X}$ & $\mathrm{X}$ & \\
\hline Boykinia occidentalis & 0.387 & 0.023 & & $\mathrm{X}$ & \\
\hline Clintonia andrewsiana & 0.365 & 0.027 & $\mathrm{X}$ & & \\
\hline Rubus spectabilis & 0.575 & 0.016 & $\mathrm{X}$ & $\mathrm{X}$ & \\
\hline Rubus parviflorus & 0.545 & 0.003 & $\mathrm{X}$ & & \\
\hline Rosa gymnocarpa & 0.408 & 0.010 & $X$ & & \\
\hline \multicolumn{6}{|l|}{ Non-natives } \\
\hline Senecio minimus & 0.516 & 0.001 & & & $\mathrm{X}$ \\
\hline Cirsium vulgare & 0.365 & 0.032 & & & $\mathrm{X}$ \\
\hline
\end{tabular}

Indicator species are grouped by herbs, shrubs, and non-natives with the species listed in order of greatest indicator value within each group. 


\section{Discussion}

Forest composition and structure on thinned and un-thinned plots exhibited significant differences from old-growth reference sites, suggesting a long recovery period from the original disturbance. One of the goals of restoration can be to help influence the recruitment of understory species, more specifically, shade tolerant understory that is typically found in old-growth Sequoia sempervirens forests. Thinned plots did not exhibit evidence of understory enhancement, however. Rather, canopy gaps created by thinning were filling in with Notholithocarpus densiflorus; tanoak seedling density on thinned plots was nearly twice that which appeared on un-thinned plots. In contrast, understory species were recovering on un-thinned plots and ISA indicated that un-thinned plots shared several indicator species with old-growth plots. Blechnum spicant (Deer fern), Oxalis oregana, Polystichum munitum, and Trillium ovatum were all found to have high importance value in lost man creek old-growth stands (Keyes \& Teraoka 2014), and appeared to be recovering in un-thinned stands, yet were lacking in thinned stands. Analysis of residual species further supported these findings with some residual species recovering on un-thinned plots while recovery of others was incomplete. The dominance of invader species on thinned plots and the lack of residual species suggested that thinning could prolong the understory recovery process.

Many variables come into play in determining understory recruitment. Light availability and proximity to stream, for example, have been shown to play an important role in understory recruitment (Waring \& Major 1964). In this study, no meaningful correlations were found between stand structure and native understory recruitment. 
However, several understory species were correlated with proximity to stream further supporting the notion that water availability is more a determining factor of understory potential than overstory density. One of the goals of the thinning treatment was to reduce density to increase understory recruitment. However, this study found no meaningful correlations between stand density and understory metrics. Moreover, thinning appears to prolong the understory recover process.

When implementing restoration plans it is important to consider overall goals. In this instance, the goal was to achieve old-growth function in second-growth redwood stands. The results of this study indicated that un-thinned sites trended towards old-growth with stands of greater age increasing in similarity to old-growth stands. Similar photosynthetic capacity has been achieved naturally in unmanaged 135 -year-old secondgrowth stands (Iberle et al. 2016), suggesting a path forwards for natural recovery. In addition, a compositional shift towards $S$. sempervirens has been shown to take place once stands reach 80 years of age (Iberle et al. 2016). In this study, we found 74-year-old un-thinned plots had the highest redwood dominance and lowest densities of all secondgrowth plots sampled, further supporting these findings.

One of the primary goals of the silvicultural thinning treatments described in this study was to accelerate the stem exclusion process (Oliver 1980). However, it appears that rather than accelerating it, thinning may have been inhibiting it by increasing the recruitment of new stems. In this study, ten years post-thinning density increased due to recruitment of new stems (Figure 6). Further, data by O'Hara et al. (2010) indicated that density increased four years post-thinning, whereas density decreased naturally on 
control sites. These findings suggest that the re-entry on thinned plots could pose significant setbacks in the recovery process from the original disturbance.

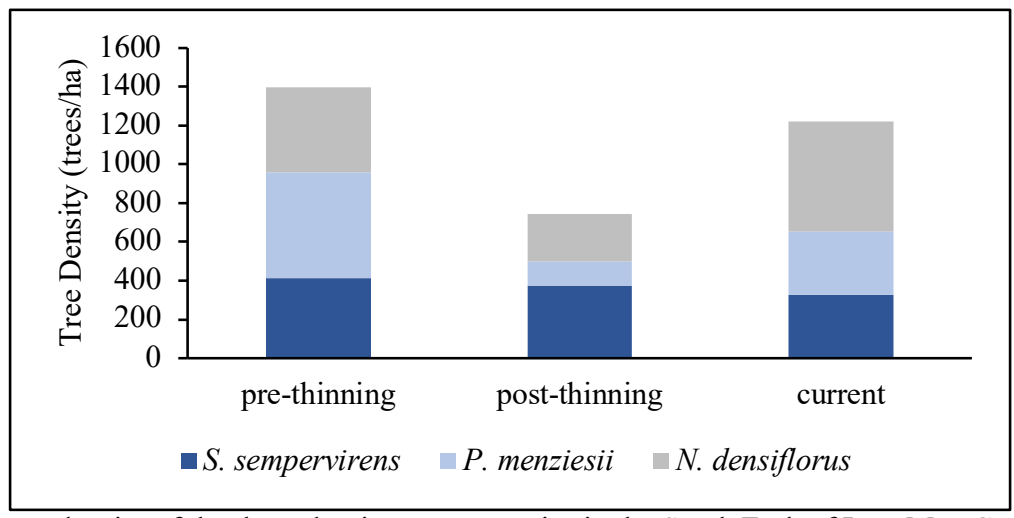

Figure 6. Average tree density of the three dominant tree species in the South Fork of Lost Man Creek treatment area. Densities presented are for areas where slopes did not exceed 30\%. Pre-thinning and post-thinning densities were obtained from data presented in Teraoka et al. (2017).

It could be argued that the recruitment of new stems could be favorable in helping to achieve a compositional shift towards $S$. sempervirens. However, in this study, $S$. sempervirens density remained the same 10 years post-thinning while density of $N$. densiflorus and P. menziesii both increased substantially 10 years post-thinning (Figure 6). Prior studies have also found that thinning fell short of shifting composition in favor of S. sempervirens (O’Hara et al. 2010; Teraoka 2014).

Increased ground disturbance caused by mechanical harvesting appears to impact understory re-establishment in some cases (Small \& McCarthy 2002). Removal of canopy causes changes in light availability, soil temperatures, and soil moisture (Bormann \& Likens 1979), and long-lived herbs are particularly vulnerable to such changes (Small \& McCarthy 2002). Particular care was taken to minimize soil disturbance on thinned sites studied, yet, understory was still impacted. Excessive amounts of slash could also have potentially impacted understory recruitment on these 
sites as slash can crush existing understory, and residual understory has been found to be significantly impacted by the presence of slash following harvest (Scherer et al. 2000). Thick layers of slash take substantial amounts of time to decompose, further extending the recovery process. Thinned sites had excessive amounts of slash remaining, even 10 years post-thinning (Figure 7, Figure 8), and native understory richness was found to be negatively correlated with slash depth.

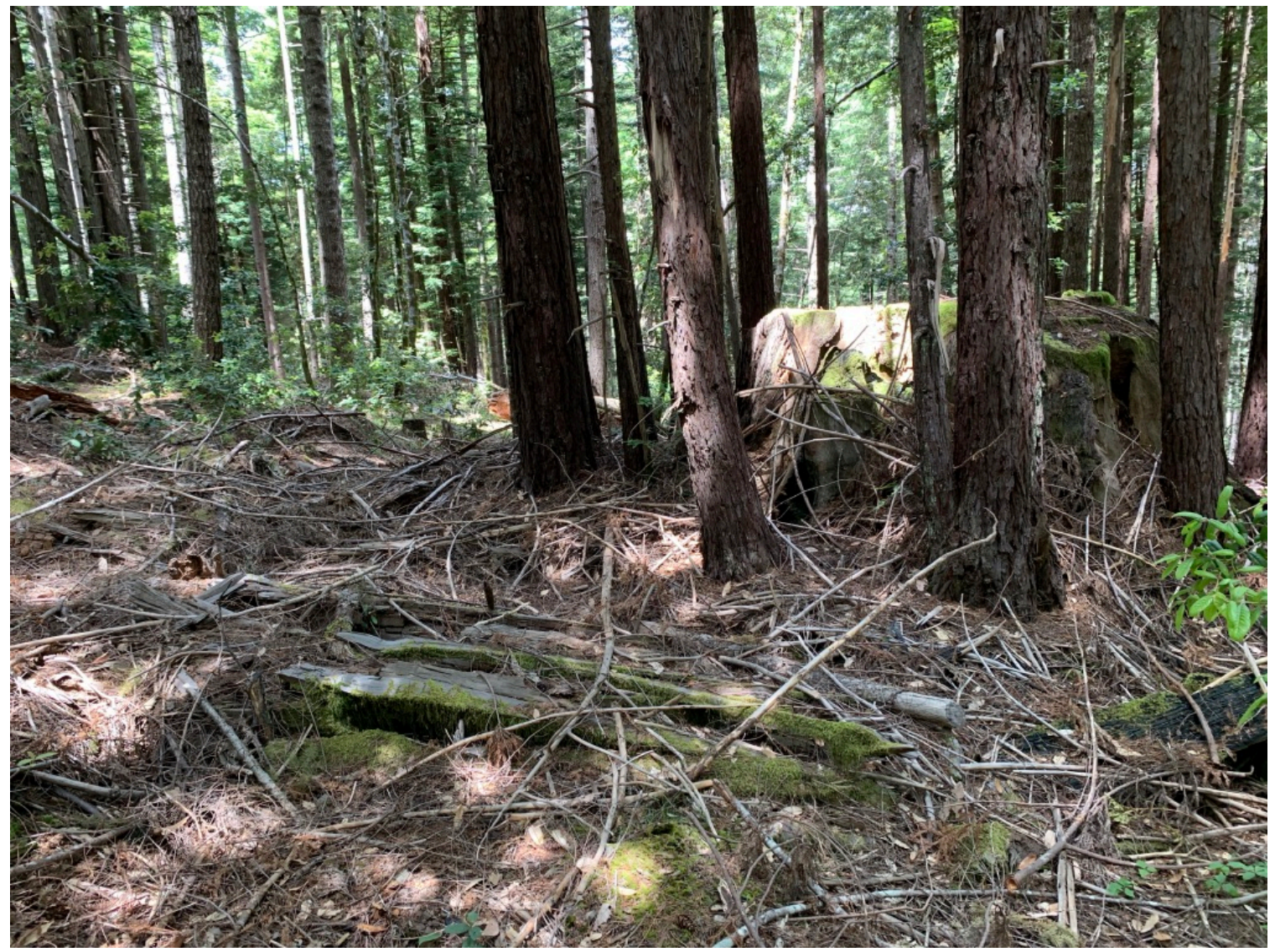

Figure 7. Example of slash remaining on thinned sites in Redwood National Park ten years post-thinning. 


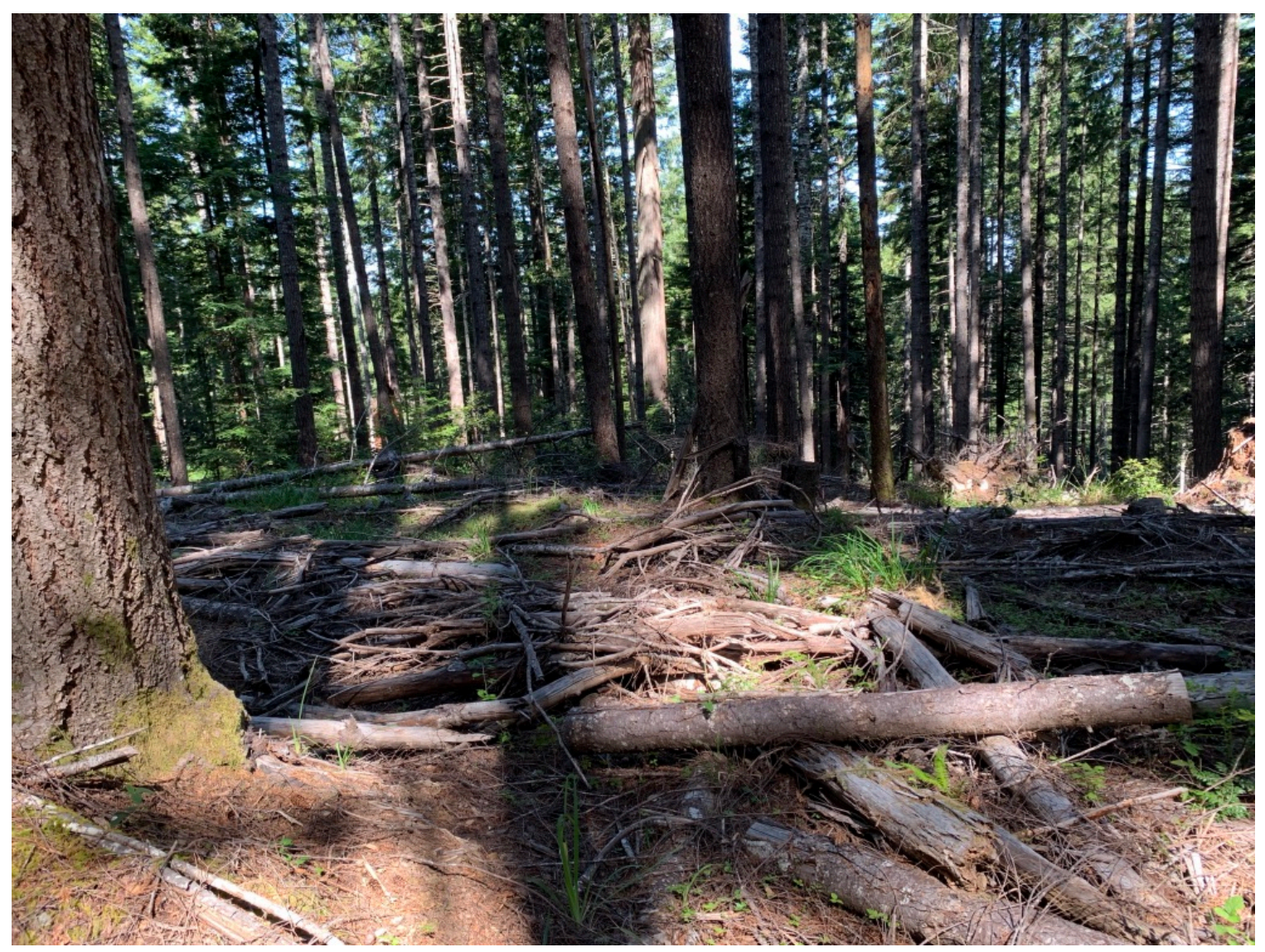

Figure 8. Example of slash remaining on thinned sites in Redwood National Park ten years post-thinning.

\section{Conclusion}

Ten years after thinning, understory recruitment on thinned plots was lacking compared to un-thinned plots. Stand density on thinned plots increased, and it appears that re-entries would be required to maintain density targets. The establishment of features found in old-growth $S$. sempervirens forests have taken centuries. The best method for achieving old-growth structure and function in previously logged forests is unknown, though, this study would suggest that using mechanical thinning to achieve such goals could pose significant setbacks for old-growth understory recruitment. 
Additional research in the ability of $S$. sempervirens to recover naturally from a historic logging disturbance could provide insight for future restoration plans. 


\section{References}

Baldwin BG, Goldman D, Keil DJ, Patterson R, Rosatti TJ, Wilken DH (2012) The Jepson manual: vascular plants of California (2nd ed.). University of California Press, Berkeley, California

Bauhus J, Puettmann K, Messier C (2009) Silviculture for old-growth attributes. Forest Ecology and Management 258(4):525-537

Berrill JP, Beal CB, LaFever D H, Dagley CM (2013) Modeling young stand development towards the old-growth reference condition in evergreen mixedconifer stands at Headwaters Forest Reserve, California. Forests 4(2):455-470

Bolsinger CL, Waddell KL (1993). Area of old-growth forests in California, Oregon, and Washington. (No. PNW-RB-197). Portland, OR: U.S. Department of Agriculture, Forest Service, Pacific Northwest Research Station.

Bormann FH, Likens GE (1979) Pattern and process in a forested ecosystem. Springer-Verlag, New York, New York, USA.

Busing RT, Fujimori T (2009) Dynamics of composition and structure in an old Sequoia sempervirens forest. Journal of Vegetation Science 13(6):785-792

Chittick A, Keyes R (2004) Holter Ridge thinning study, Redwood National Park: preliminary results of a 25 -year retrospective. USDA Forest Service Gen. Tech Rep. PSW-GTR-194. 2007

De Cáceres M (2013) How to use the indicspecies package (ver. 1.7.1). R Foundation for Statistical Computing, Vienna, Austria

De Cáceres M, Legendre P (2009) Associations between species and groups of sites: indices and statistical inference. Ecology 90:3566-3574

De Cáceres M, Legendre P, Moretti M (2010) Improving indicator species analysis by combining groups of sites. Oikos 119(10):1674-1684

Dodson EK, Peterson DW (2010) Dry coniferous forest restoration and understory plant diversity: the importance of community heterogeneity and the scale of observation. Forest Ecology and Management 260(10):1702-1707

Dufrene M, Legendre P (1997) Species assemblages and indicator species: the need for a flexible asymmetrical approach. Ecological Monographs 67(3):345-366 
Falk KJ, Burke DM, Elliott KA, Holmes SB (2008) Effects of single-tree and group selection harvesting on the diversity and abundance of spring forest herbs in deciduous forests in southwestern Ontario. Forest Ecology and Management 255(7):2486-2494

Frelich LE (2002) Forest dynamics and disturbance regimes: studies from temperate evergreen-deciduous forests. Cambridge University Press, Cambridge, UK

Gilliam FS (2002) Effects of harvesting on herbaceous layer diversity of a central Appalachian hardwood forest in West Virginia, USA. Forest Ecology and Management 155(1)L33-43

Halpern C, Spies T (1995) Plant species diversity in natural and managed forests of the pacific northwest. Ecological Applications 5(4):913-934

Iberle BG, Sillett SC, Pelt RV, Andre M (2016) Ninety-two years of tree growth and death in a second-growth redwood forest. Gen. Tech. Rep. PSW-GTR-258. Albany, CA: U.S. Department of Agriculture, Forest Service, Pacific Southwest Research Station: 35-38

Jenkins MA, Parker GR (1999) Composition and diversity of ground-layer vegetation in silvicultural openings of southern Indiana forests. The American Midland Naturalist 142(1):1-16

Jones DA, O'Hara KL (2012) Carbon density in managed coast redwood stands: implications for forest carbon estimation. Forestry: An International Journal of Forest Research 85(1):99-110

Kahmen A, Jules ES (2005) Assessing the recovery of a long-lived herb following logging: trillium ovatum across a 424-year chronosequence. Forest Ecology and Management 210(1):107-116

Kern CC, Palik BJ, Strong TF(2006) Ground-layer plant community responses to evenage and uneven-age silvicultural treatments in Wisconsin northern hardwood forests. Forest Ecology and Management 230(1):162-170

Keyes CR, Teraoka EK (2014) Structure and composition of old-growth and unmanaged second-growth riparian forests at Redwood National Park, USA. Forests 5(2):256-268

Legendre P, Legendre L (2012) Numerical Ecology, Amsterdam: Elsevier 3(24) 
Limm EB, Simonin KA, Bothman AG, Dawson T (2009) Foliar water uptake: a common water acquisition strategy for plants of the redwood forest. Oecologia 161: 449-459

Loya DT, Jules ES (2008) Use of species richness estimators improves evaluation of understory plant response to logging: a study of redwood forests. Plant Ecology 194(2):179-194

Mantgem PJ, Teraoka JR, LaFever DH, Lalemand LB (2017) Growth of coast redwood and Douglas-fir following thinning in second-growth forests at Redwood National Park and Headwaters Forest Reserve. Gen. Tech. Rep. PSW-GTR-258. Albany, CA: U.S. Department of Agriculture, Forest Service, Pacific Southwest Research Station: 279-286, 258, 279-286.

Meier AJ, Bratton SP, Duffy DC (1995) Possible ecological mechanisms for loss of vernal-herb diversity in logged eastern deciduous forests. Ecological Applications 5(4):935-946

National Parks Service United States Department of Interior [NPS] (2008) Redwood National Park south fork Lost Man Creek second growth forest restoration environmental assessment. Orick, California

National Parks Service United States Department of Interior [NPS] (2014) Redwood National Park middle fork Lost Man Creek second-growth forest restoration environmental assessment. Orick, California

O'Hara KL, Nesmith JCB, Leonard L, Porter DJ (2010) Restoration of old forest features in coast redwood forests using early-stage variable-density thinning. Restoration Ecology 18:125-135

O'Hara KL, Narayan L, Cahill KG (2015) Twelve-year response of coast redwood to precommercial thinning treatments. Forest Science 61(4):780-789

Oksanen J, Guillaume Blanchet F, Friendly M, Kindt R, Legendre P, McGlinn D, Minchin PR, O'Hara RB, Simpson GL, Solymos, P, Stevens M, Szoecs,E, Wagner H (2019) Vegan: community ecology package. R package version 2.5-4

Oksanen J (2015) Multivariate Analysis of ecological communities in R. Vegan Tutorial 43

Oliver C (1980) Forest development in North America following major disturbances. Forest Ecology and Management 3:153-168 
Petersen AK, Russell W (2017) A comparison of stand structure and composition following selective-harvest at Byrne-Milliron Forest. Gen. Tech. Rep. PSW-GTR258. Albany, CA: U.S. Department of Agriculture, Forest Service, Pacific Southwest Research Station: 247-258, 258, 247-258.

RStudio Team (2015) RStudio: Integrated development for r. RStudio, Inc., Boston, MA

Russell WH, Jones C (2001) The effects of timber harvesting on the structure and composition of adjacent old-growth coast redwood forest, California, USA. Landscape Ecology 16(8):731-741

Russell W (2009) The influence of timber harvest on the structure and composition of riparian forests in the coastal redwood region. Forest Ecology and Management 257:1427-1433

Russell W, Michels K (2011) Stand development on a 127-yr chronosequence of naturally regenerating Sequoia sempervirens (Taxodiaceae) forests. Madroño 229-24

Russell W, Sinclair J, Michels K (2014) Restoration of coast redwood (Sequoia sempervirens) forests through natural recovery. Open Journal of Forestry 04:106111

Russell W (2020) Herbaceous understory indicators of post-harvest recovery in coast redwood (Sequoia sempervirens) forests. Open Journal of Forestry 10:204-216

Scherer G, Zabowski D, Java B, Everett R (2000) Timber harvesting residue treatment. Part II. Understory vegetation response. Forest Ecology and Management $126(1): 35-50$

Small CJ, McCarthy BC (2002) Effects of simulated post-harvest light availability and soil compaction on deciduous forest herbs. Canadian Journal of Forest Research 32(10):1753-1762

Teraoka JR (2012) Forest restoration at Redwood National Park: a case study of an emerging program. In: Proceedings of Coast Redwood Forests in a Changing California: A Symposium for Scientists and Managers. Gen. Tech. Rep. PSWGTR-238. Albany, CA: Pacific Southwest Research Station, Forest Service, U.S. Department of Agriculture. Pp. 561-569, 238, 561-569

Teraoka JR, Mantgem PJ, Keyes CR (2017) Low thinning and crown thinning of two severities as restoration tools at Redwood National Park. Gen. Tech. Rep. PSW- 
GTR-258. Albany, CA: U.S. Department of Agriculture, Forest Service, Pacific Southwest Research Station: 259-266, 258, 259-266

Van Pelt R, Franklin J (2000) Influence of canopy structure on the understory environment in tall, old-growth, conifer forests. Canadian Journal of Forest Research 30(8):1231-1245

Waring R, Major J (1964) Some vegetation of the California coastal redwood region in relation to gradients of moisture, nutrients, light, and temperature. Ecological Monographs 34(2):167-215 


\section{Chapter 3: Conclusion}

Active management techniques have been used successfully in a variety of ecosystem types. Short lived forests that are custom to frequent large-scale disturbances tend to be more receptive to restoration through the use of silvicultural manipulation. However for long lived forests, such as the Sequoia sempervirens dominated forest of northern California, using silviculture as a restoration technique has had mixed results. Density reduction achieved is short lived, and understory appears to be significantly impacted. Features found in old-growth S. sempervirens forests have developed over thousands of years, even the oldest second-growth stands are under 200 years old. It is not clear how these forests will recover naturally over their lifetime, as these lifespans span millennia. The focus of restoration should shift from achieving density similar to old-growth, to restoring ecosystem composition and function to these recovering second-growth stands. 


\section{References}

Axelrod, D (1985) Rise of the grassland biome, Central North America. Botanical Review 51(2):163-201

Baldwin BG, Goldman D, Keil DJ, Patterson R, Rosatti TJ, Wilken DH (2012) The Jepson manual: vascular plants of California (2nd ed.). University of California Press, Berkeley, California

Baker WL (1993) Spatially heterogeneous multi-scale response of landscapes to fire suppression. Oikos 66(1):66-71

Barbour M, Lydon S, Borchert M, Popper M, Whitworth V, \& Evarts J (2001) Coast redwood: a natural and cultural history. Cachuma Press, Los Olivos, California

Barro SC, Conard SG (1991) Fire effects on California chaparral systems: an overview. Environment International 17(2-3):135-149

Battles JJ, Shlisky AJ, Barrett RH, Heald RC, \& Allen-Diaz BH (2001) The effects of forest management on plant species diversity in a Sierran conifer forest. Forest Ecology and Management 146(1): 211-222

Bauhus J, Puettmann K, Messier C (2009) Silviculture for old-growth attributes. Forest Ecology and Management 258(4):525-537

Belnap J, Gillette, DA (1997) Disturbance of biological soil crusts: impacts on potential wind erodibility of sandy desert soils in southeastern Utah. Land Degradation \& Development 8(4):355-362

Berrill JP, Beal CB, LaFever D H, Dagley CM (2013) Modeling young stand development towards the old-growth reference condition in evergreen mixedconifer stands at Headwaters Forest Reserve, California. Forests 4(2):455-470

Betts MG, Wolf C, Ripple WJ, Phalan B, Millers KA, Duarte A, Butchart S, Levi T (2017) Global forest loss disproportionately erodes biodiversity in intact landscapes. Nature 547(7664):441-444

Boe KN (1966) Windfall after experimental cuttings in old-growth redwood. Proceedings, Society of American Foresters. Detroit, MI. USA. October 24-28 1965 (1966), pp. 59-63

Bolsinger CL, Waddell KL (1993). Area of old-growth forests in California, Oregon, and Washington. (No. PNW-RB-197). Portland, OR: U.S. Department of Agriculture, Forest Service, Pacific Northwest Research Station. 
Bormann FH, Likens GE (1979) Pattern and process in a forested ecosystem. Springer-Verlag, New York, New York, USA.

Brokaw NVL (1985) Gap-phase regeneration in a tropical forest. Ecology 66(3):682-687

Bugmann H (2001) A review of forest gap models. Climatic Change 51(3): 259-305

Burke D, Elliott K, Holmes S, Bradley D (2008) The effects of partial harvest on the understory vegetation of southern Ontario woodlands. Forest Ecology and Management 255(7):2204-2212.

Burton JI, Zenner EK, Frelich LE, Cornett MW (2009) Patterns of plant community structure within and among primary and second-growth northern hardwood forest stands. Forest Ecology and Management 258(11):2556-2568.

Busing RT, Fujimori T (2009) Dynamics of composition and structure in an old Sequoia sempervirens forest. Journal of Vegetation Science 13(6):785-792

Brown PM, Swetnam TW (1994) A cross-dated fire history from coast redwood near Redwood National Park, California. Canadian Journal of Forest Research 24(1):21-31

Brown PM (2007) What was the role of fire in coast redwood forests? Gen. Tech. Rep. PSW-GTR-194. Albany, CA: Pacific Southwest Research Station, Forest Service, U.S. Department of Agriculture; p.553

Cambi M, Certini G, Neri F, Marchi E (2015) The impact of heavy traffic on forest soils: a review. Forest Ecology and Management 338124-138

Chen J, Saunders SC, Crow TR, Naiman RJ, Brosofske KD, Mroz GD, Franklin JF (1999) Microclimate in forest ecosystem and landscape ecology variations in local climate can be used to monitor and compare the effects of different management regimes. BioScience 49(4):288-297

Chittick A, Keyes R (2004) Holter Ridge thinning study, Redwood National Park: preliminary results of a 25-year retrospective. USDA Forest Service Gen. Tech Rep. PSW-GTR-194. 2007

Clements F (1916) Plant succession; an analysis of the development of vegetation. Carnegie Institution of Washington, DC 
Clements FE, Weaver JE, Hanson HC (1929) Plant competition; an analysis of community functions. Carnegie institute of Washington, Washington, DC

De Cáceres M (2013) How to use the indicspecies package (ver. 1.7.1). R Foundation for Statistical Computing, Vienna, Austria

De Cáceres M, Legendre P (2009) Associations between species and groups of sites: indices and statistical inference. Ecology 90:3566-3574

De Cáceres M, Legendre P, Moretti M (2010) Improving indicator species analysis by combining groups of sites. Oikos 119(10):1674-1684

Devine WD, Harrington CA (2007) Release of Oregon white oak from overtopping douglas-fir: effects on soil water and microclimate. Northwest Science 81(2):112124

Devine WD, Harrington CA (2006) Changes in Oregon white oak (Quercus garryana Dougl. ex Hook.) following release from overtopping conifers. Trees 20(6):747756

Dodson EK, Peterson DW (2010) Dry coniferous forest restoration and understory plant diversity: the importance of community heterogeneity and the scale of observation. Forest Ecology and Management 260(10):1702-1707

Drury W, Nisbet I (1973) Succession. Journal of the Arnold Arboretum 54(3): $331-368$

Dufrene M, Legendre P (1997) Species assemblages and indicator species: the need for a flexible asymmetrical approach. Ecological Monographs 67(3):345-366

Ellum DS (2009) Floristic diversity in managed forests: demography and physiology of understory plants following disturbance in southern New England forests. Journal of Sustainable Forestry 28(1-2):132-151

Falk KJ, Burke DM, Elliott KA, Holmes SB (2008) Effects of single-tree and group selection harvesting on the diversity and abundance of spring forest herbs in deciduous forests in southwestern Ontario. Forest Ecology and Management 255(7):2486-2494

Fan BM, Dong Y (2001) Percentage of forest cover in different historic periods of China. Journal of Beijing Forestry University 23(4):60-66

Forman RTT, Godron M (1981) Patches and structural components for a landscape ecology. BioScience 31(10):733-740 
Franklin JF, Lindenmayer D, MacMahon JA, McKee A, Magnuson J, Perry DA, Foster D (2000). Threads of continuity. Conservation in Practice 1(1):8-17

Franklin JF, Spies TA, Pelt RV, Carey AB, Thornburgh DA, Berg DR, Chen J (2002) Disturbances and structural development of natural forest ecosystems with silvicultural implications, using Douglas-fir forests as an example. Forest Ecology and Management 155(1):399-423

Franklin JF, Mitchell RJ, Palik BJ (2007) Natural disturbance and stand development principles for ecological forestry (No. NRS-GTR-19). Newtown Square, PA: U.S. Department of Agriculture, Forest Service, Northern Research Station

Frelich LE (2002) Forest dynamics and disturbance regimes: studies from temperate evergreen-deciduous forests. Cambridge University Press, Cambridge, UK

Fritz E (1932) The role of fire in the coast redwood region. University of California College of Agriculture, Agricultural Experiment Station, Berkeley, California

Gilliam FS (2002) Effects of harvesting on herbaceous layer diversity of a central Appalachian hardwood forest in West Virginia, USA. Forest Ecology and Management 155(1)L33-43

Gilliam FS (2007) The Ecological significance of the herbaceous layer in temperate forest ecosystems. BioScience 57(10):845-858

Gleason HA (1926) The individualistic concept of the plant association. Bulletin of the Torrey Botanical Club 53(1):7-26

Halpern C, Spies T (1995) Plant species diversity in natural and managed forests of the pacific northwest. Ecological Applications 5(4):913-934

Hanover A, Russell W (2018) Understory recovery in coast redwood communities: a case study comparing a naturally recovering and an actively managed forest. Open Journal of Forestry 08:489

Harr RD, Nichols RA (1993) Stabilizing forest roads to help restore fish habitats: a northwest Washington example. Fisheries 18(4):18-22

Hughes A (2010) Disturbance and diversity: an ecological chicken and egg problem. Nature Education Knowledge 3(10):48

Iberle BG, Sillett SC, Pelt RV, Andre M (2016) Ninety-two years of tree growth and 
death in a second-growth redwood forest. Gen. Tech. Rep. PSW-GTR-258. Albany, CA: U.S. Department of Agriculture, Forest Service, Pacific Southwest Research Station: 35-38

Jacobs DF, Cole DW, McBride JR (1985) Fire history and perpetuation of natural coast redwood ecosystems. Journal of Forestry 83(8):494-497

Jameson MJ, Robards TA (2007) Coast redwood regeneration survival and growth in Mendocino county, California. Western Journal of Applied Forestry 22(3):171175

Jansson KJ, Johansson J (1998) Soil changes after traffic with a tracked and a wheeled forest machine: a case study on a silt loam in Sweden. Forestry: An International Journal of Forest Research 71(1):57-66

Jenkins MA, Parker GR (1999) Composition and diversity of ground-layer vegetation in silvicultural openings of southern Indiana forests. The American Midland Naturalist 142(1):1-16

Jones DA, O’Hara KL (2012) Carbon density in managed coast redwood stands: implications for forest carbon estimation. Forestry: An International Journal of Forest Research 85(1):99-110

Kaplan JO, Krumhardt KM, Zimmermann N (2009) The prehistoric and preindustrial deforestation of Europe. Quaternary Science Reviews 28(27):3016-3034

Kahmen A, Jules ES (2005) Assessing the recovery of a long-lived herb following logging: trillium ovatum across a 424-year chronosequence. Forest Ecology and Management 210(1):107-116

Kern CC, Palik BJ, Strong TF(2006) Ground-layer plant community responses to evenage and uneven-age silvicultural treatments in Wisconsin northern hardwood forests. Forest Ecology and Management 230(1):162-170

Keyes CR, Teraoka EK (2014) Structure and composition of old-growth and unmanaged second-growth riparian forests at Redwood National Park, USA. Forests 5(2):256-268

Konôpka B, Zach P, Kulfan J (2016) Wind - an important ecological factor and destructive agent in forests. Forestry Journal 62(2):123-130

Legendre P, Legendre L (2012) Numerical Ecology, Amsterdam: Elsevier 3(24) 
Lenihan J (1990) Forest associations of Little Lost Man Creek, Humboldt County, California: Reference-level in the hierarchical structure of old-growth coastal redwood vegetation. Madroño : A West American Journal of Botany 37(2):69-87

Limm EB, Simonin KA, Bothman AG, Dawson T (2009) Foliar water uptake: a common water acquisition strategy for plants of the redwood forest. Oecologia 161: 449-459

Liu M, Tian H (2010) China's land cover and land use change from 1700 to 2005 : estimations from high-resolution satellite data and historical archives. Global Biogeochemical Cycles 24(3)

Lorimer CG, Porter DJ, Madej MA, Stuart JD, Veirs SD, Norman SP, Libby WJ (2009) Presettlement and modern disturbance regimes in coast redwood forests: implications for the conservation of old-growth stands. Forest Ecology and Management 258(7):1038-1054

Loya DT, Jules ES (2008) Use of species richness estimators improves evaluation of understory plant response to logging: a study of redwood forests. Plant Ecology 194(2):179-194

Mahony TM, Stuart JD (2000) Old-growth forest associations in the northern range of coastal redwood. Madroño 47(1):53-60

Mantgem PJ, Teraoka JR, LaFever DH, Lalemand LB (2017) Growth of coast redwood and Douglas-fir following thinning in second-growth forests at Redwood National Park and Headwaters Forest Reserve. Gen. Tech. Rep. PSW-GTR-258. Albany, CA: U.S. Department of Agriculture, Forest Service, Pacific Southwest Research Station: 279-286, 258, 279-286.

McNabb D, Startsev A, Nguyen H (2001) Soil wetness and traffic level effects on bulk density and air-filled porosity of compacted boreal forest soils Soil Sci. Soc. Am. J. 65(2001):1238-1247

Meier AJ, Bratton SP, Duffy DC (1995) Possible ecological mechanisms for loss of vernal-herb diversity in logged eastern deciduous forests. Ecological Applications 5(4):935-946

Metlen KL, Fiedler CE(2006) Restoration treatment effects on the understory of ponderosa pine/Douglas-fir forests in western Montana, USA. Forest Ecology and Management 222(1):355-369 
Michels K, Russell W (2016) Variation In old-growth coast redwood (Sequoia sempervirens) reference sites in Mendocino County, California. Madroño, 63: $258-267$

Miesel JR, Boerner REJ, Skinner CN (2009) Mechanical restoration of California mixedconifer forests: does it matter which trees are cut? Restoration Ecology 17(6):784-795.

Moola FM, Vasseur L (2004) Recovery of late-seral vascular plants in a chronosequence of post-clearcut forest stands in coastal Nova Scotia, Canada. Plant Ecology 172(2):183-197

National Parks Service United States Department of Interior [NPS] (2008) Redwood National Park south fork Lost Man Creek second growth forest restoration environmental assessment. Orick, California

National Parks Service United States Department of Interior [NPS] (2014) Redwood National Park middle fork Lost Man Creek second-growth forest restoration environmental assessment. Orick, California

Nelson CR, Halpern CB, Antos JA (2007) Variation in responses of late-seral herbs to disturbance and environmental stress. Ecology 88(11):2880-2890

O'Hara KL, Nesmith JCB, Leonard L, Porter DJ (2010) Restoration of old forest features in coast redwood forests using early-stage variable-density thinning. Restoration Ecology 18:125-135

O'Hara KL, Narayan L, Cahill KG (2015) Twelve-year response of coast redwood to precommercial thinning treatments. Forest Science 61(4):780-789

Oksanen J, Guillaume Blanchet F, Friendly M, Kindt R, Legendre P, McGlinn D, Minchin PR, O'Hara RB, Simpson GL, Solymos, P, Stevens M, Szoecs,E, Wagner H (2019) Vegan: community ecology package. R package version 2.5-4

Oksanen J (2015) Multivariate Analysis of ecological communities in R. Vegan Tutorial 43

Oliver WW, Lindquist JL, Strothmann RO (1994) Young-growth redwood stands respond well to various thinning intensities. Western Journal of Applied Forestry 9(4):106-112

Oliver C (1980) Forest development in North America following major disturbances. Forest Ecology and Management 3:153-168 
Perry DW, Breshears LW, Gradillas GE, Berrill JP (2016) Thinning intensity and easeof-access increase probability of bear damage in a young coast redwood forest. Journal of Biodiversity Management \& Forestry 2016

Petersen AK, Russell W (2017) A comparison of stand structure and composition following selective-harvest at Byrne-Milliron Forest. Gen. Tech. Rep. PSW-GTR258. Albany, CA: U.S. Department of Agriculture, Forest Service, Pacific Southwest Research Station: 247-258, 258, 247-258.

Pickett S, White P (1985) The ecology of natural disturbance and patch dynamics. Orlando, Fla.: Academic Press

Rapp V (2002) Restoring complexity: second-growth forests and habitat diversity. Pacific Northwest Research Station. Corvallis, OR

Rapp V (2003) New findings about old-growth forests. Pacific Northwest Research Station. Science update 4(June 2003)

Roberts MR, Gilliam FS (1995) Patterns and mechanisms of plant diversity in forested ecosystems: implications for forest management. Ecological Applications 5(4):969-977

Roni P, Beechie TJ, Bilby RE, Leonetti FE, Pollock MM, Pess GR (2002) A Review of stream restoration techniques and a hierarchical strategy for prioritizing restoration in pacific northwest watersheds. North American Journal of Fisheries Management 22(1):1-20

RStudio Team (2015) RStudio: Integrated development for r. RStudio, Inc., Boston, MA

Russell W, Carnell K, Mcbride J (2001) Black bear (Ursus americanus pallas) feeding damage across timber harvest edges in northern California coast redwood (Sequoia sempervirens[D. Don] Endl.) forests, USA. Natural Areas Journal 21:324-329

Russell WH, Jones C (2001) The effects of timber harvesting on the structure and composition of adjacent old-growth coast redwood forest, California, USA. Landscape Ecology 16(8):731-741

Russell W (2009) The influence of timber harvest on the structure and composition of riparian forests in the coastal redwood region. Forest Ecology and Management 257:1427-1433 
Russell W, Michels K (2011) Stand development on a 127-yr chronosequence of naturally regenerating Sequoia sempervirens (Taxodiaceae) forests. Madroño $229-24$

Russell W, Sinclair J, Michels K (2014) Restoration of coast redwood (Sequoia sempervirens) forests through natural recovery. Open Journal of Forestry 04:106111

Russell W (2020) Herbaceous understory indicators of post-harvest recovery in coast redwood (Sequoia sempervirens) forests. Open Journal of Forestry 10:204-216

Sawyer JO, Sillett SC, Libby WJ, Dawson TE, Popenoe JH, Largent DO, Van Pelt R, Veirs SD, Noss RF, Thornburgh DA, Del Tredici P $\left(2000_{a}\right)$ Redwood trees, communities and ecosystems: a closer look. In Noss, R.F. (Ed.) The Redwood Forest: History, Ecology, and Conservation of the Coast Redwoods, Island Press, Washington DC, USA

Sawyer JO, Gray J, West GJ, Thornburgh DA, Noss RF, Engbeck JH, Marcot BG, Raymond R (2000b) History of redwood and redwood forests. In R.F. (Ed.) The Redwood Forest: History, Ecology, and Conservation of the Coast Redwoods, Island Press, Washington DC, USA

Scherer G, Zabowski D, Java B, Everett R (2000) Timber harvesting residue treatment. Part II. Understory vegetation response. Forest Ecology and Management 126(1):35-50

Small CJ, McCarthy BC (2002) Effects of simulated post-harvest light availability and soil compaction on deciduous forest herbs. Canadian Journal of Forest Research 32(10):1753-1762

Sousa WP (1984) The role of disturbance in natural communities. Annual Review of Ecology and Systematics 15:353-391

Spies TA (2009) Science of old growth or journey into wonderland pages 31-43 In: Spies TA, Duncan SL (Eds.), Old growth in a new world. Island Press, Washington DC

Tansley AG (1935) The use and abuse of vegetation concepts and terms. In Ecology 16(3):284-307

Teraoka JR (2012) Forest restoration at Redwood National Park: a case study of an emerging program. In: Proceedings of Coast Redwood Forests in a Changing California: A Symposium for Scientists and Managers. Gen. Tech. Rep. PSWGTR-238. Albany, CA: Pacific Southwest Research Station, Forest Service, U.S. Department of Agriculture. Pp. 561-569, 238, 561-569 
Teraoka JR, Mantgem PJ, Keyes CR (2017) Low thinning and crown thinning of two severities as restoration tools at Redwood National Park. Gen. Tech. Rep. PSWGTR-258. Albany, CA: U.S. Department of Agriculture, Forest Service, Pacific Southwest Research Station: 259-266, 258, 259-266

Thomas SC, Halpern CB, Falk DA, Liguori DA, Austin KA (1999) Plant diversity in managed forests: understory responses to thinning and fertilization. Ecological Applications 9(3): 864-879

United States Department of Agriculture (2014) U.S. forest resource facts and historical trends. United States Department of Agriculture, Forest Service FS-1035

Urban DL, Shugart HH (1992) Individual-based models of forest succession. Plant succession: theory and prediction 249-292

Uys RG, Bond WJ, Everson TM (2004) The effect of different fire regimes on plant diversity in southern African grasslands. Biological Conservation, 118(4):489499

Van Pelt R, Franklin J (2000) Influence of canopy structure on the understory environment in tall, old-growth, conifer forests. Canadian Journal of Forest Research 30(8):1231-1245

Waring R, Major J (1964) Some vegetation of the California coastal redwood region in relation to gradients of moisture, nutrients, light, and temperature. Ecological Monographs 34(2):167-215

Watt A (1947). Pattern and process in the plant community. Journal of Ecology, $35(1 / 2): 1-22$

Whitmore TC (1978) Gaps in the forest canopy. In P.B. Tomlinson and M.H. Zimmermann, ed., Tropical Trees as Living Systems. pp. 639-655. Cambridge University Press, London

Williams M (2003) Deforesting the Earth: from prehistory to global crisis. University of Chicago Press

Wirth, C., Gleixner, G., \& Heimann, M. (2009) Old-growth forests: function, fate and Value. Springer-Verlag Berlin Heidelberg 207

Yamamoto SI (1992)The gap theory in forest dynamics. The Botanical Magazine = Shokubutsu-Gaku-Zasshi 105(2):375-383 


\section{Appendix A}

Table 5. Mean percent cover for each understory species encounter within the three treatment types at Redwood National Park.

\begin{tabular}{|c|c|c|c|}
\hline & Mean & Mean & Mean \\
\hline Native Herbs & old-growth & un-thinned & thinned \\
\hline Polystichum munitum & 10.842 & 9.088 & 0.217 \\
\hline Oxalis oregana & 4.717 & 0.717 & 0.308 \\
\hline Trillium ovatum & 0.429 & 0.183 & 0.008 \\
\hline Cardamine californica & 0.367 & 0.138 & 0.050 \\
\hline Dryopteris arguta & 0.292 & 0.283 & - \\
\hline Viola sempervirens & 0.275 & 0.338 & 0.383 \\
\hline Asuram caudatum & 0.250 & 0.038 & - \\
\hline Lysimachia latifolia & 0.213 & 0.146 & 0.238 \\
\hline Prosartes hookeri & 0.196 & 0.054 & - \\
\hline Maianthemum racemosum & 0.183 & - & - \\
\hline Galium aparine & 0.179 & 0.258 & 0.217 \\
\hline Anemone deltoidea & 0.146 & - & - \\
\hline Goodyera oblongifolia & 0.100 & 0.008 & 0.029 \\
\hline Adenocaulon bicolor & 0.092 & - & - \\
\hline Aralia californica & 0.088 & 0.167 & - \\
\hline Iris douglasiana & 0.075 & 0.054 & 0.154 \\
\hline Lathyrus vestitus & 0.071 & 0.013 & 4.033 \\
\hline Vancouveria planipetala & 0.071 & 0.042 & 0.013 \\
\hline Lilium columbianum & 0.067 & 0.042 & 0.021 \\
\hline Osmorhiza berteroi & 0.063 & 0.021 & - \\
\hline Actaea rubra & 0.046 & - & - \\
\hline Claytonia sibirica & 0.042 & 0.100 & 0.046 \\
\hline Stachys mexicana & 0.042 & 0.058 & 0.021 \\
\hline Sanicula crassicaulis & 0.038 & - & - \\
\hline Blechnum spicant & 0.033 & 0.096 & - \\
\hline Whipplea modesta & 0.033 & 0.121 & 2.742 \\
\hline Clintonia andrewsiana & 0.021 & - & - \\
\hline Pteridium aquilinum var. pubescens & 0.008 & 0.038 & 0.467 \\
\hline Polypodium scouleri & 0.008 & - & - \\
\hline Calypso bulbosa & 0.008 & - & - \\
\hline Corallorhiza maculata & 0.008 & 0.004 & 0.025 \\
\hline Dicentra formosa & 0.008 & - & - \\
\hline Cephalanthera austiniae & 0.004 & - & - \\
\hline Petasites frigidus & 0.004 & - & - \\
\hline Achlys triphylla & 0.004 & - & - \\
\hline Prunella vulgaris & - & 0.004 & - \\
\hline Clinopodium douglasii & - & 0.008 & - \\
\hline
\end{tabular}


Hieracium albiflorum

Anisocarpus madioides

Boykinia elata

Fragaria vesca

Asyneuma prenanthoides

\section{Native Shrubs}

Gaulltheria shallon

Vaccinium ovatum

Rhododendron macrophyllum

Vaccinium parvifolium

Rubus spectabilis

Berberis nervosa

Rubus parviflorus

Lonicera hispidula

Rosa gymnocarpa

Rubus ursinus

Ribes sanguineum

Rubus leucodermis

Morella californica

Sambucus racemosa

Frangula purshiana

\section{Non-natives}

Leucanthemum vulgare

Rubus armeniacus

Cirsium vulgare

Senecio minimus

Myosotis latifolia

$\begin{array}{ccc}- & 0.013 & 0.004 \\ - & - & 0.025 \\ - & 0.038 & 0.004 \\ - & - & 0.021 \\ - & - & 0.042\end{array}$

\begin{tabular}{ccc} 
old-growth & un-thinned & thinned \\
10.425 & 1.521 & 0.317 \\
9.693 & 9.200 & 1.488 \\
6.746 & 2.775 & 0.742 \\
2.175 & 0.192 & 0.033 \\
1.500 & 0.579 & 0.017 \\
1.200 & 0.358 & 0.325 \\
0.346 & 0.042 & - \\
0.079 & 0.067 & 0.063 \\
0.046 & 0.000 & - \\
0.025 & 0.329 & 0.088 \\
0.017 & 0.000 & 0.008 \\
- & 0.079 & 0.021 \\
- & 0.050 & - \\
- & 0.338 & - \\
- & 0.038 & - \\
old-growth & un-thinned & thinned \\
- & 0.008 & - \\
- & - & 0.004 \\
- & - & 0.017 \\
- & - & 0.083 \\
\hline & & 0.008
\end{tabular}

